\title{
Attribution and reattribution : an examination of the ideas underlying reattribution practice
}

Citation for published version (APA):

den Boer, D-J. (1992). Attribution and reattribution : an examination of the ideas underlying reattribution practice. [Doctoral Thesis, Maastricht University]. Rijksuniversiteit Limburg.

https://doi.org/10.26481/dis.19920228db

Document status and date:

Published: 01/01/1992

DOI:

10.26481/dis.19920228db

Document Version:

Publisher's PDF, also known as Version of record

\section{Please check the document version of this publication:}

- A submitted manuscript is the version of the article upon submission and before peer-review. There can be important differences between the submitted version and the official published version of record.

People interested in the research are advised to contact the author for the final version of the publication, or visit the DOI to the publisher's website.

- The final author version and the galley proof are versions of the publication after peer review.

- The final published version features the final layout of the paper including the volume, issue and page numbers.

Link to publication

\footnotetext{
General rights rights.

- You may freely distribute the URL identifying the publication in the public portal. please follow below link for the End User Agreement:

www.umlib.nl/taverne-license

Take down policy

If you believe that this document breaches copyright please contact us at:

repository@maastrichtuniversity.nl

providing details and we will investigate your claim.
}

Copyright and moral rights for the publications made accessible in the public portal are retained by the authors and/or other copyright owners and it is a condition of accessing publications that users recognise and abide by the legal requirements associated with these

- Users may download and print one copy of any publication from the public portal for the purpose of private study or research.

- You may not further distribute the material or use it for any profit-making activity or commercial gain

If the publication is distributed under the terms of Article $25 \mathrm{fa}$ of the Dutch Copyright Act, indicated by the "Taverne" license above, 


\title{
ATTRIBUTION AND REATTRIBUTION
}

\author{
An examination of the ideas underlying \\ reattribution practice
}


ses 


\title{
ATTRIBUTION AND REATTRIBUTION
}

\author{
An examination of the ideas underlying \\ reattribution practice
}

\section{PROEFSCHRIFT}

ter verkrijging van de graad van doctor aan de Rijksuniversiteit Limburg te Maastricht, op gezag van de Rector Magnificus, Prof. Mr. M.J. Cohen, volgens het besluit van het College van Dekanen, in het openbaar te verdedigen

op vrijdag 28 februari 1992 om 14.00 uur

door

Dirk-Jan den Boer

Geboren te Eindhoven op 13 april 1963 


\section{Promotores:}

Prof. dr. G.J. Kok

Prof. dr. A.F.M. van Knippenberg (Katholieke Universiteit Nijmegen)

\section{Co-promotor:}

Dr. R.M. Meertens

Beoordelingscommissie:

Prof. dr. M.A. van den Hout (voorzitter)

Prof. dr. F. Försterling (Universität Bielefeld)

Prof. dr. P.G. Knipschild

Prof. dr. H.G. Schmidt

Prof. dr. H.A.M. Wilke (Rijksuniversiteit Leiden)

CIP-DATA KONINKLIJKE BIBLIOTHEEK, DEN HAAG

Boer, Dirk-Jan den

Aftribution and reattribution : an examination of the ideas underlying reattribution practice / Dirk-Jan den Boer ; [ill. by the author]. - [S.l. : s.n.]. - III.

Thesis Maastricht. - With ref. - With summary in Dutch. ISBN 90-9004728-X

NUGI 714

Produktie: Datawyse Maastricht, Ruud Leliveld Druk: Krips Repro Meppel 


\section{Acknowledgements}

Although this thesis is presented as the work of one author, many people helped me complete it. Especially my advisors, Gerjo Kok, Ad van Knippenberg and Ree Meertens contributed, each in their own way, a lot. Ree was always there to discuss experimental procedures and come up with some better way to present research findings. Gerjo was available to discuss the major issues or help decide which route to take. If experimentation became too stressfull it was always possible to discuss this, social psychology, or the latest Eddings over diner at the Perroen. Thanks to observing this project from a greater distance Ad would always spot illogical, incomplete arguments, or weird results. Without their help it would have been impossible to finish this project.

Besides these three advisors other people contributed as well. Ger van Wunnik and Theo van Aertz took care of the simple but crucial things like chairs, tables, cables, screens, electrodes and, of course, coffee. Bart van de Heuvel was always there to help me set up the network or spend his free evenings to find that last, nasty, bug in my programs. Angelique van de Kar made the first experiment more enjoyable by assisting me as an experimenter. Harm Hospers and Thijs Lenderink checked different versions of this manuscript. They are the only ones who know how many mistakes are left in a manuscript I consider 'finished'.

During this project I have spent some time abroad. This was possible thanks to the hospitality of the Department of Health Education at the University of North Carolina. Vic Strecher and his Pips made me discover the horrors of translating experimental procedures, to real-life situations. They, furthermore, made sure that I felt at ease in Chapel Hill.

Less concrete, but at least as important, was the social support offered by my colleagues at the Department of Health Education in Maastricht, friends, family and, last but certainly not least, Karin. It would be too much to say that without their support this dissertation would not have been written, but I can not imagine that I would have enjoyed it so much.

Utrecht, October 1991 



\section{Contents}

Chapter 1 Overview

1.1 Introduction 9

1.2 Weiner's attribution theory 11

Dimensionality of causes 11

Attributional effects on cognitions, emotions

$\begin{array}{ll}1.3 \text { Lacunae in the literature } & 18\end{array}$

Causality in attribution theory $\quad 18$

$\begin{array}{ll}\text { Methodological considerations } & 19\end{array}$

Task performance and social facilitation 20

1.4 Experiments $\quad 21$

1.5 General discussion $\quad 27$

Chapter 2 Measurements effects in reattribution research

2.1 Introduction $\quad 31$

2.2 Method 33

2.3 Results 34

2.4 Discussion $\quad 35$

Chapter 3 Effects of differences on attributional dimensions on cognitions and behavior

3.1 Introduction

3.2 Method experiment 1

3.3 Results and discussion experiment 1

3.4 Method experiment 2 48

3.5 Results and discussion experiment $2 \quad 50$

3.6 General discussion $\quad 55$

Chapter 4 The effects of attributions and task difficulty on cognitions, emotions and performance

4.1 Introduction

4.2 Method 64

4.3 Results 66

$\begin{array}{ll}\text { 4.4 Discussion } & 75\end{array}$

References 


\section{Chapter 1}

\section{Overview}

\subsection{Introduction}

During the last 20 years considerable attention has been devoted to so called "reattribution" programs (see Försterling, 1985, 1986, 1988). These programs assume that causes people hold responsible for an outcome determine reactions when the same task has to be made again. Changes in perceived causes for previous performances are expected to result in changes in emotions people experience, the way they expect to perform on comparable tasks in the future and how they actually perform on these tasks. Failing at losing weight, for example, leads to less confidence, and less intent to try again if this failure is ascribed to one's metabolism compared to attributing to something circumstantial.

Reattribution programs try to induce people to explain their performances in such a way that an attribution is made which ensures confidence, feelings of control and persistence. In the case of failure, lack of effort is usually the preferred attribution. Lack of effort is presumed to be a cause which may be changed and controlled, thus resulting in confidence that one is able to succeed. These feelings of confidence in turn are supposed to lead to higher persistence at a task and $d_{s}$ ultimately, higher performance. Trainings employing this kind of approach to behavioral change are generally successful (Den Boer, Meertens \& Kok, 1989; Försterling, 1985; Weary, Stanley \& Harvey, 1989) and have been applied to many different situations. Chapin and Dyck (1976) and Fowler and Peterson (1981), for instance, succeeded in improving reading skills of children. Others succeeded in improving arithmetic skills of children (Dweck, 1975; Schunk, 1981, $1982,1983,1984$ ), the score of subjects on anagram tasks (Andrews \& Debus, 1978), lowering drop-out rates at highschool and improving academic success (Wilson \& Linville, 1982, 1985). Furthermore, it may be noted that techniques similar to the ones used in reattribution trainings are used successfully by cognitive therapists (e.g. Beck, 1967, 1976; Den Boer, Kok, \& Meertens, 1989; Ellis, 1962; Försterling, 1986, 1988).

Recently, health educators have started to incorporate attributional techniques in their interventions. At first, health education inter- 
ventions consisted mostly of telling people what was wrong about their behavior, hoping that this message would be a sufficient inducement to behavior change. As we now know, however, this is not sufficient; people need to be motivated to change, and people need knowledge on how to change. On the one hand changing attributions for previous performances is expected to change self-confidence and expectation of success with respect to a task. These variables may be considered as variables which enhance the motivation to attempt to change. On the other hand, inducing people to perceive other causes for their failures may help them gain knowledge about how to change behavior, in order to be successful in the future.

Theoretically, reattribution programs rely heavily on attribution theory. This theory is used to derive answers to the question of which attribution produces, under what circumstances and by what mechanisms, have the most beneficial effects on emotions, cognitions, persistence and performance. This thesis reports studies important to both attribution and reattribution theory. Although the issues investigated are inspired by the practice of reattribution training, the studies reported are of a theoretical nature.

First, it is investigated whether positive effects of reattribution training are an effect of the specific content of the attributional change (e.g. attributing to effort), or of parts of the attributional process itself. Reattribution interventions make subjects think about probable causes for their performance. Second, it is examined whether the assumptions of reattribution training about the causes to which people should attribute in order to achieve the best effects on cognitions and performance are correct. The third aim of this thesis, finally, is to provide some insight into the conditions under which attributions to effort do lead to better performance, and the conditions under which they do not. More specifically, on the basis of social facilitation theory, it will be predicted that an attribution of failure to effort is only profitable for relatively simple tasks.

Because the theoretical foundation of reattribution trainings is Weiner's attribution theory, this short introduction to the thesis is followed by a description of attribution theory. Discussing this theory as well as the presentation of empirical data on reattribution interventions, will lead to the formulation of several theoretical questions, inspired by lacunae in the literature, relevant to reattribution practice. Subsequently, a broad outline of the experiments addressing these questions (reported in chapters 2,3 and 4 ) will be given and the main results will be discussed. Finally, general conclusions will be formulated and consequences of the obtained results for attribution theory and reattribution practice will be discussed. 


\subsection{Weiner's attribution theory}

Before exploring the theoretical rationale of reattribution trainings, it is important to delineate the broad field of attribution theory. Many reviews of attribution theory start by making a similar point: there is no single attribution theory (Harvey \& Weary, 1984; Hewstone, 1989; Kelley \& Michela, 1980; Ross \& Fletcher, 1985; Weary et al., 1989). Weary et al. (1989), for instance, state on the first page of their latest overview of attribution theory:

"..., we would like to point out that there is no monolithic theory in this domain of work. As soon will become evident to the reader, there are no well-accepted, singular sets of assumptions or hypotheses, nor are there general conclusions concerning attribution processes that are tied together in a coherent logical network" (p. 3).

An important distinction between the quite diverse theories in the attribution field is made by Kelley (1967). He distinguishes between attribution and attributional theories. Attribution theories are concerned with why, how and what kind of attributions people make, while attributional theories are concerned with the consequences of different attributions people make for different outcomes. The part of Weiner's theory of importance to this thesis clearly belongs to this second theoretical domain. However, for the sake of brevity, in the remainder of this overview the term attribution theory is used to refer to the attributional part of Weiner's theory.

Attribution theory provides answers about how attributions influence cognitions, emotions and behavior, and it also explains why effort attributions are presumed to be "better" than other attributions. Before discussing the theory, however, more information is needed about the kind of attributions people make and how these attributions can be categorized. After discussing the dimensionality of causes, effects of attributions on expectation of success, emotions and behavior will be discussed.

\section{Dimensionality of causes}

For each event or outcome a multitude of possible causes may be considered responsible. Failure at an exam may be attributed, among a multitude of other causes, to lack of effort, disturbing noises, unfair grading, a lack of ability, the difficulty of the exam, bad luck, or exam anxiety. On a more abstract level, however, there are only a few factors on which causes vary.

Weiner, Frieze, Kukla, Reed, Rest and Rosenbaum (1971) distinguish two dimensions on which causes vary. The first dimension, 
internality, represents the distinction between personal characteristics like affect, ability or effort, and environmental characteristics like task difficulty, luck or the weather. This dimension may be compared to a distinction made in the early work of Heider (1958), in which it is suggested that people search for the causal structure of events by distinguishing between causes in the environment and causes in the person. Rotter (1966) created a typology of people based on this so called locus of control dimension. He distinguishes between internals, people who perceive their environment as under their own control and externals, people who think that events are caused by external circumstances:

Weiner and colleagues, furthermore, observed that within the internality dimension causes still differ from each other on a conceptual levell. Ability, for instance, may be viewed as relatively stable over time, while effort may be viewed as unstable and fluctuating. A second dimension of causality, namely stability, was therefore introduced. This dimension indicates whether a cause changes over time. Weiner and colleagues furthermore contended that both dimensions might be viewed as orthogonal. This is shown in Table 1.

Table 1. Dimensions of attributions combined.

\begin{tabular}{lcc} 
& Stable & Unstable \\
\hline Internal & Ability & Effort \\
External & Task difficulty & Luck \\
\hline
\end{tabular}

Rosenbaum (1972) suggested yet another dimension of causality, namely controllability. Effort, mood and fatigue, which are all internal, unstable causes, differ from each other in the extent to which volitional control might be exerted over them. Effort expenditure at a task may be controlled by a person; mood and fatigue, however, are far less controllable. This third dimension may, according to the theory, be added as a separate, third dimension to the $2 \times 2$ classification of causes.

Several researchers have criticized this representation of causal structure (e.g. Darley \& Goethals, 1980; Ross \& Fletcher, 1985). This criticism may be thought of as consisting of three different aspects. First, some remarks can be made about this classification on a conceptual level. Second, critique is inspired by the discrepancy between the way psychologists and laymen use this classification. Finally, it will 
be shown that empirical evidence does not always support the proposed orthogonality of dimensions.

On a conceptual level, critique relates to the combination of controllability with the other two dimensions. Locus of causality and stability were viewed as parts of a $2 \times 2$ taxonomy, and the introduction of controllability should, theoretically, increase this to a $2 \times 2$ $\times 2$ taxonomy. The combination of external and controllable or stable and controllable causes, however, is difficult to envision (see Weiner (1986, pp. 49-50), and Hewstone and Antaki (1988) for a discussion of this problem). When, for example, a cause is viewed as stable it implies that it does not change over time, while controllability refers to the possibility of the person being able to change the cause. Talking about controllable, stable causes, thus seems to be a contradiction in terms. By the same token, external causes by definition are difficult to control by a person. Weiner (1986) suggests a solution to this latter problem by defining controllability as "controllable by anyone", allowing one to make a $2 \times 2 \times 2$ taxonomy. On a conceptual level this solution is adequate, but when it is to be applied in the achievement domain, however, it is not entirely satisfactory. In this domain the important factor is whether or not a cause is controllable by oneself. Whether or not another person has control over a cause is irrelevant to how the person having to perform the task is going to change his or her behavior. The other solution Weiner proposes for this problem is to view all external causes as uncontrollable. In the achievement domain this solution is satisfactory. In the case of helping behavior, however, it might be unsatisfactory (Weiner, 1986, pp. 192-205).

The second set of problems signalled by researchers (e.g. Darley \& Goethals, 1980), refers to how people actually use this classification. Research shows that effort is sometimes viewed as stable (he or she is lazy or hard working) and that ability, when learning is considered, is viewed as unstable. The classification, however, should only be interpreted as meaning that, in general, task difficulty and luck are viewed as more external than effort and ability, and ability and task difficulty as more stable than luck and effort, when referring to achievement-related events (Weiner, 1983). Re-search clearly supports this view (e.g. Russell, McAuley \& Tarico, 1987). However, when these specific causes are used to manipulate attributional dimensions, care should be taken to check whether or not this a priori classification fits with the classification used by subjects. Weiner (1979, p. 6) explicitly warns that "the relative placement of a cause on a dimension is not invariant over time or between people," and continues, "Inasmuch as attribution theory deals with phenomenal causality, such personal interpretations must be taken into account". 
Finally, research has been conducted on the relations between the three dimensions. Weiner (1986) discusses severall studies aimed at determining how people perceive causes. He concludes that there is unambiguous support for the contention that there are three dimensions of causality ( $p$. 64). Whereas a conceptual problem with the combination of stability and controllability was signalled, no research is reported on this point. Research has shown, however, that the dimensions of internality and controllability, in particular, are highlly correlated with each other (Anderson, 1983; Den Boer, Kok, Van Knippenberg \& Peeters, 1991; Hewstone \& Antaki, 1988). Den Boer et al. (1991) have shown that causes not only vary on the dimension of controllability but also on whether or not a cause is controllable by oneself or by others. Not surprisingly, measures for controllability by self correlate positively with measures for locus of causality, while measures for controllability by others correlate negatively with locus of causality Ignoring this distinction would lead to an estimate of the correlation between locus of causality and controllability near zero, indicating orthogonality. This, however, is caused by the artefact of adding two different concepts, of which one correlates positively, and the other negatively with locus of causality.

\section{Attributional effects on cognitions, emotions and behavior.}

Now that a frame of reference has been provided, it is possible to return to the original question: Which attributions for previous performances are most beneficial to cognitions, emotions, persistence and performance? The part of attribution theory concerned with this question describes the attributional determinants of cognitions, emotions and behavior (Weiner, 1985, 1986). It states that people react differently to an event if they attribute the event to different causes. For example, one will feel more confident of success if one attributes previous successes to one's own ability compared to attributing previous successes to having made easy tasks.

Weiner's theory (see Figure 1) states that differences on underlying dimensions, rather than differences in attribution, lead to differences in cognitions, emotions and behavior. Stability of attributions is supposed to influence expectations of success. Attributing failure to stable causes is more likely to lead to expectations of renewed failure. Because stable causes, by definition, are unlikely to change they will still be unchanged when one attempts to succeed at the same task again. Similarly, if one attributes failure to unstable causes one is more likely to expect success the next time one is performing the task. The next time one attempts to succeed at the task, the cause, because it is unstable, might have changed. By the same logic, this effect should be reversed after success: the more one 


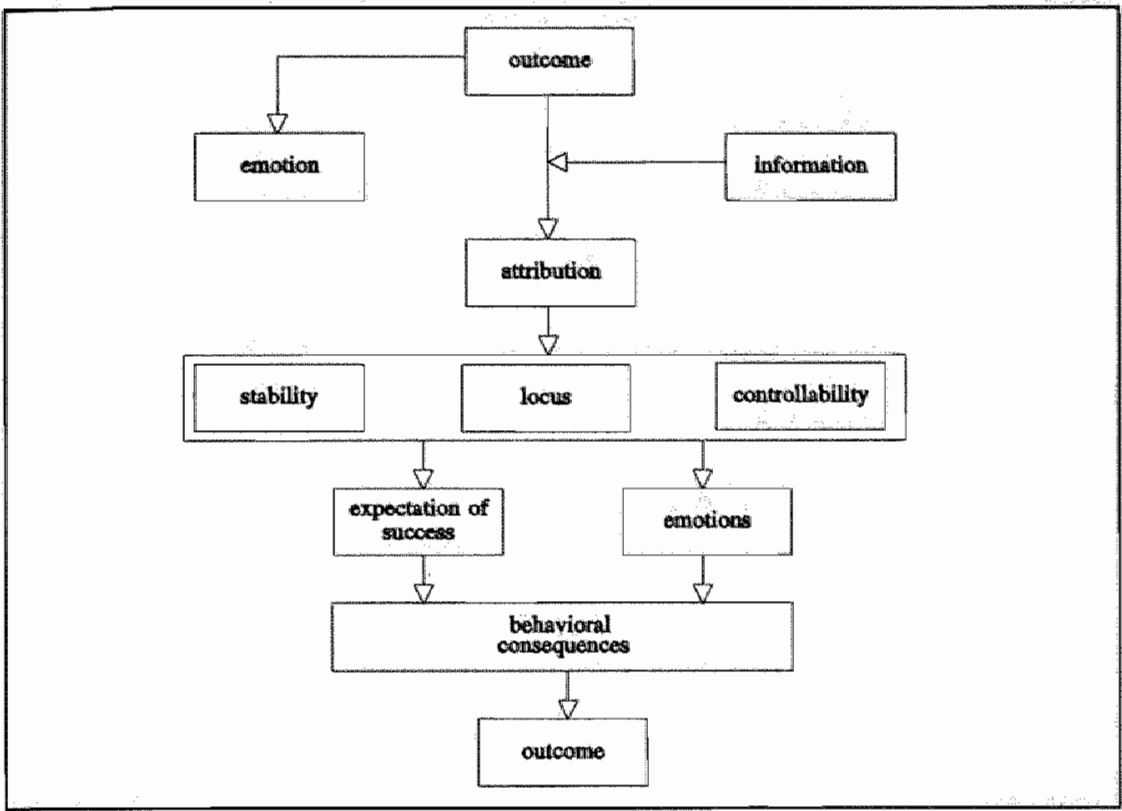

Figure 1. Attribution theory (adapted from Weiner, 1985).

assumes that stable factors caused success, the more one will expect success to be repeated.

Furthermore, it is assumed that lowered expectations of success lead to deteriorated task behavior. Lowered success expectancies are assumed to lead to less energy investments in a task; individuals will think it is not efficient to invest a lot of energy in a task of which they think they may not succeed. It is this lack of energy invested in a task that causes low performance. These relations between stability of attributions on the one hand, and expectation of success, behavior and performance on the other, may be referred to as the cognitive component of Weiner's theory.

Aside from this cognitive component, an affective component may be distinguished within attribution theory. This part of the theory describes the relation between perceptions of locus of causality and controllability on the one hand, and emotions and behavior on the other. Performance itself is assumed to have consequences for the emotions experienced. High performance will, in general, lead to more positive emotions. Low performance to more negative emotions. More important, though, is the assumption that different attributions or, more precisely, differences on the dimensions of internality and controllability, will lead to different emotions. An attribution for 


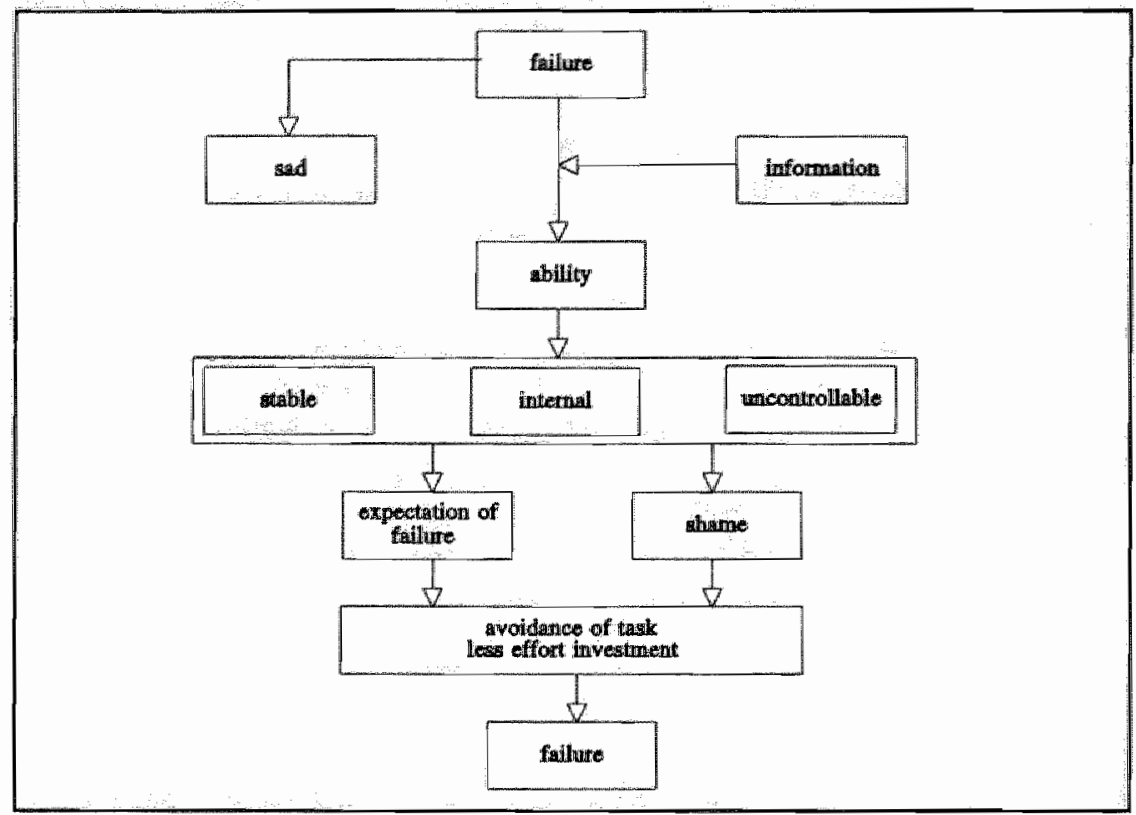

Figure 2. Situation before change in attributions.

previous failure to effort, for instance, will lead to guilt, while an attribution for failure to ability will lead to shame. According to Weiner, emotions elicited by attributions for success or failure can be either motivating or debilitating. Motivating emotions (guilt for instance) lead to better task performance while debilitating emotions (shame) llead to worse task performance.

The above reasoning leads to the conclusion that failure attributions should, in order to cause improved task performance, be unstable, internal and controllable. If other attributions have been made, it might be beneficial to change them. Changing stable attributions to unstable attributions ensures that people not necessarily expect renewed failure, resulting in relatively high expectations of success. Controllable causes may be changed by the attributor himself: more energy can be invested in the task, leading to more persistence and improved performance. Finally, the combination of internall and controllable causes for failure ensures motivating emotions.

Figure 2 and 3 provide a specific example of this idea. An internal, stable and uncontrollable attribution for failure (lack of ability) is changed to an internal, unstable and controllable attribution (lack of 


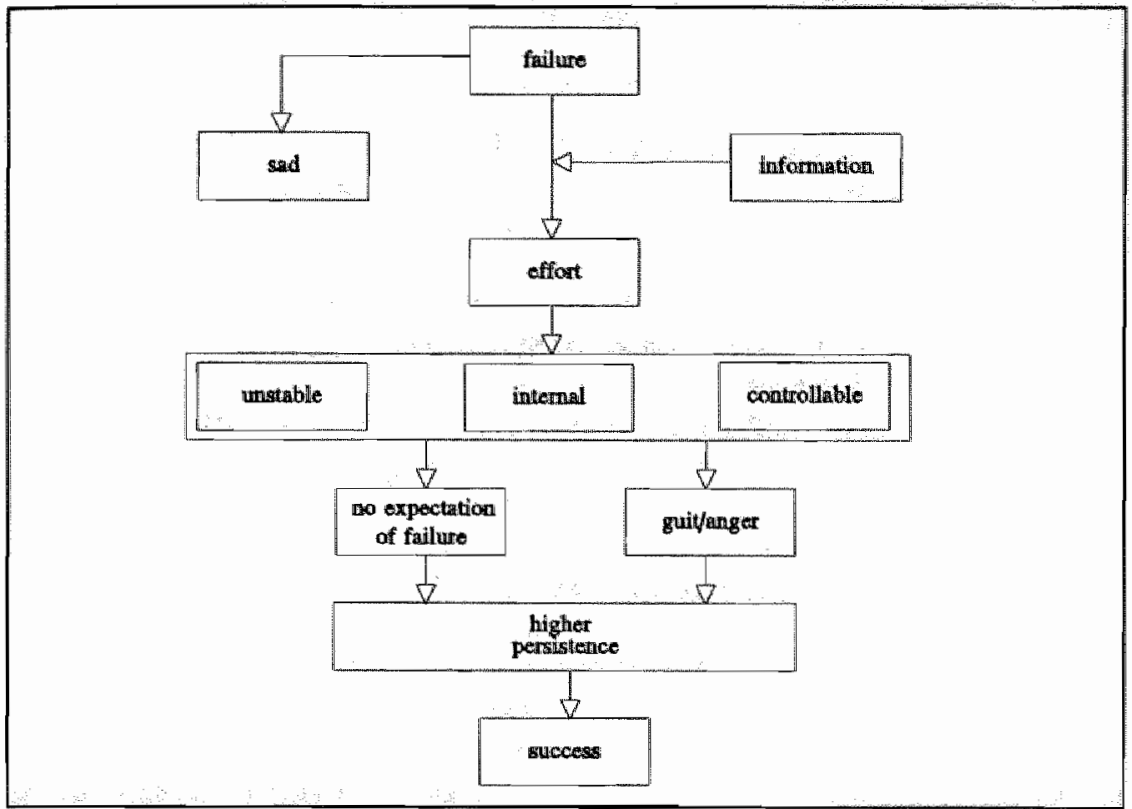

Figure 3. Situation after change in attributions.

effort). The resulting effects on expectation of success, persistence, emotions and performance are also depicted.

Helping people lose weight is a good example of how this theory is applied. The causes people who repeatedly failed at losing weight, perceive as responsible for these failures are predominantly internal, stable and uncontrollable (Haisch, Rduch \& Hailsch, 1985; Hospers, Kok \& Strecher, 1990). As a consequence of repeated failures, people often think that they are incapable of losing weight. They think, for instance, that they have a metabolism that makes them gain weight, even when they consistently eat small amounts of low-calorie food. This is a typical case of a dysfunctionall attribution. Changing this stable, internal and uncontrollable attribution to unstable, internal and controllable should, by means of the mechanisms discussed above, result in a higher likelihood of a successful attempt at losing weight in the future. 


\subsection{Lacunae in the literature}

The above discussion of attribution theory might give the suggestion that attribution theory is a well established theory, needing no further research. To some extent this is true, large parts of the theory are beyond discussion. Careful examination of the literature, however, reveals several lacunae. First of all, an analysis of the literature reveals that more evidence is needed about whether or not relations proposed in attribution theory are really causal. Second, a look at the practice of reattribution reveals the possibility of an alternative explanation, based on methodological considerations, for the beneficial effects of these types of intervention. Finally, it will be signalled that in (re)attribution theory no distinction based on task characteristics is made. It will be suggested that theories on task performance and social facilitation theory may be used to extend attribution theory.

\section{Causality in attribution theory}

Although support for attribution. theory seems overwhelming, it should be noted that there has hardly been any research permitting causal inferences. Most of the studies conducted in the area of attributions made for own success or failure, are correlational or use hypothetical situations. Correlational studies (e.g. Eiser \& Van Der Pligt, 1986; Eiser, Van Der Pligt, Raw \& Sutton, 1985; Hospers et al., 1990) measure attributions for previous failures and relate these to expectations of success (and sometimes) behavior if the same task has to be made again. Scenario studies (e.g. Neale \& Friend, 1972; Rosenbaum, 1972) present subjects with a hypothetical situation and ask them to state what they would feel and/or do in this situation. Both types of studies are valuable in gaining information about how attributions are related to cognitions and behavior. However, they do not permit inferences about causal relations between attributions made for own, actually experienced, behavior and the consequences thereof. Only one study is known to us in which attributions were manipulated and where expectation of success was a dependent variable (Riemer, 1975). This study, however, was only aimed at the effect of different attributions after success, and what is more, did not find any support for the proposed relation between stability of attributions and expectation of success (see Weiner (1983) for an explanation of the absence of effects in this study). The same holds if one reviews the literature on the affective component of the theory. Again, most studies are correlational or use a scenario methodology, only two studies are experimental (McFarland \& Ross, 1982; Riemer, 1975).

For reattribution practice, the causality of the relations between attributions on the one hand and cognitions, emotions, behavior, and 
performance on the other, are of utmost importance. Reattribution interventions will only work when reattribution of own performance on a task will result in better performance. It is for this reason that the second and third study reported, have as their main goal to find evidence for the causality of the relations proposed in Weiner's attribution theory.

\section{Methodological considerations}

It may be argued that the reattribution paradigm already proved that changing attributions leads to differences in behavior. Or, in other words, at least for effort causal relations appear to have been demonstrated. It is possible, however, to formulate alternative explanations for the positive results of reattribution studies.

The predominant research design in this type of study is a comparison between subjects who received attributional training and subjects who did not (Andrews \& Debus, 1978; Fowler \& Peterson, 1981; Haisch et al, 1985; Medway \& Venino, 1982). Attributional training teaches subjects to attribute their failures to lack of effort invested in the task. The manipulation of attribution is considered to be the cause of any behavioral or cognitive changes that occur after the training. However, comparisons between subjects who were encouraged to attribute to effort and subjects not encouraged to do so, are often confounded with the fact that subjects who received the attributional intervention were forced to make a much more explicit causal search than subjects in the control condition. They not only had to consider whether the information the experimenter gave them about the causes for their success or failure was correct, but, at least in the studies mentioned above, they also had to complete several attributional questionnaires checking whether or not the manipulations worked. Completing an attribution questionnaire forces subjects to make a very explicit causal search. Asking subjects about attributions, as is done in reattribution studies, will often change the subject's train of thought. Making attributions provides one with the possibility of prediction and control (Kelley, 1967), giving one the opportunity to consider what might be done to replicate or avoid the previous experience with the task at hand. Having subjects who fail or succeed think about attributions makes them consider in a systematic way why they failed or succeeded. This provides an opportunity to make a realistic estimate of what went right or wrong. If subjects acted according to this information, measuring attributions may be expected to have a positive effect on behavior.

This appraisal leads to the following alternative explanation for the beneficial effects found in reattribution studies. It may well be that measurement of attributions has a positive effect on subsequent 
behavior. Making subjects explicitly think about attributions provides them with the opportunity to make an estimate of what went right or wrong. Acting according to this information should enable one to replicate success or avoid failure. The first study of this thesis addresses this alternative explanation. The beneficiality of attributional interventions is hypothesized to be due, at least partly, to a measurement effect.

\section{Task performance and social facilitation}

Attribution theory does not distinguish between types of task people perform, but, it seems plausible that task characteristics might influence the effects of reattribution interventions (Den Boer, Kok \& Meertens, 1989). With this idea in mind the views put forward by Kahneman (1973; see also Manstead \& Semin, 1980) with regard to task performance and energy allocation seem relevant to reattribution interventions.

Kahneman (1973) suggests that in the execution of easy tasks, subjects do not activate all available energy resources, but tend to perform on a sub-optimal level, retaining some amount of spare capacity which in principle may be used to improve performance. On complex tasks, however, subjects are inclined to mobilize all their energy in performing the task. In other words, easy tasks tend to elicit relaxed task performance, while complex tasks incite maximum effort expenditure from the start. This implies that attributional interventions might be capable of enhancing performance on easy tasks, whereas such interventions might not be effective in improving performance on complex tasks.

Research on social facilitation and inhibition (cf. Paulus, 1983; Wilke \& Van Knippenberg, 1988; Zajonc, 1965) demonstrates that, given complex tasks, enhanced arousal may even lead to deterioration of task performance. In other words, social facilitation theory would predict that to the extent that emotions, elicited by certain attributional explanations for failure, bring about arousal they may inhibit subsequent performance on complex or difficult tasks. On easy tasks, however, emotions and the accompanying arousal, associated with attributing failure to effort, would lead to the amelioration of task performance.

A more attribution-oriented explanation would assume that attributing failure to effort might, in the case of complex or difficult tasks, have two partly conflicting effects. On the one hand it is assumed to be beneficial because it may enhance expectations of success and, thus, persistence. On the other hand, it might evoke levels of emotions that result in "irrelevant processing" (cf. Paulus, 1983). These two effects might counteract and, as a consequence, 
attributing failure to effort would only be more effective than other attributions in terms of variables like expectation of success. On behavioral variables, however, this beneficial effect would be countered by the negative effect of enhanced arousal accompanying the intense emotions associated with attributions to effort. Extending this argument implies that, with regard to improving task performance on complex tasks, attributing failure to other causes than lack of effort might be worth considering (see also Brown \& Weiner, 1984; Clifford, 1986,ab; Covington \& Omelich, 1979,a,b,c, 1984; Wilson \& Linville, 1982, 1985). The fourth, and final experiment addresses these questions.

\subsection{Experiments}

This overview started by asking which attributions; under what circumstances and by what mechanisms, would produce the most beneficial effects on emotions, cognitions, behavior and performance. The resulting theoretical discussion led to the discussion of several lacunae in attribution theory. These lacunae are addressed in the four experiments reported in this thesis. These studies are reported in extenso in the chapters 2,3 , and 4 of this thesis. This chapter will only discuss the main points of these experiments as well as the relations between experiments. Those interested in operationalizations and statistical details are refered to the respective chapters.

The first experiment (see chapter 2) investigated whether positive effects of reattribution studies may, partly, be explained by the fact that subjects are induced to think about attributions because they have to complete attribution questionnaires. In this study subjects were randomly assigned to one of four conditions. They experienced either (manipulated) success or failure on a task and completed either an attributional questionnaire or a filler questionnaire, having nothing to do with attributions. After completing this questionnaire subjects were given the same task, in a different version, again. Dependent measure in this experiment was change in performance.

Analyses of the data revealed that measuring attributions leads, as predicted, to change in performance. Compared to the condition where attributions were not measured, subjects who had to complete an attribution questionnaire showed greater improvement of their performance. This, however, was true for failure only. After success an effect in the other direction was found. Subjects who completed an attributional questionnaire after success showed less performance increment compared to subjects who made the filler task. This latter effect, however, did not reach significance. 
Subsequent within-cell analyses revealled that for subjects in the failure condition in which attributions were measured, performance increment was positively related to attributing to task difficulty. Attributions to task difficulty, in turn, were highly correlated with attributions to effort. This pattem of correlations suggests that the conclusion that one should work harder might best be reached by attributing to task difficulty. These results suggest that the combination of an effort and a task difficulty attribution seems to have a better effect on performance than attributing to effort alone. Perhaps effort attributions raise levels of emotions (e.g. guilt) that are unpleasant, while a motivating amount of guilt is readied when one concludes that one has not worked hard enough to succeed, considering the difficulty level of the task. Or, a slightly different explanation, it could be that people may have initially under estimated the difficulty of the task. Failure feedback may have prompted them to find the task more difficult in retrospect and, in line with Kahneman's views on effort expenditure, realized that this task requires more effort investment than they initially thought.

Although the detrimental effect of measuring attributions after success did not reach significance, a tentative explanation for this effect will be given. People generally make attributions in a selfserving way (Ross \& Fletcher, 1985). Success is mostly thought of as caused by one's own ability or effort. Pointing out the possibility of different causes, as is implicitly done in an attributional questionnaire, may make people doubt whether or not their success was their own doing. This might mean that they will attribute more to causes like task-ease and luck, which are causes that do not lead to the conclusion that one should invest effort in the task. This line of reasoning might explain why measuring attributions after success may have a detrimental effect on performance.

In order to investigate which attributions have the most positive effects on cognitions, emotions, and behavior, two experiments were conducted. In the first experiment (see chapter 3 , experiment 1) subjects were randomly assigned to one of eight conditions. The first experimental factor consisted, as in the previous experiment, of (manipulated) success or failure. The second factor represented internality of attributions, and the third factor stability of attributions. These latter two factors were manipulated by telling subjects that their results were due to either their ability, the effort they invested, the difficulty of the task or luck. Dependent measures were expectation of success, persistence and performance. Subjects performed an experimental task before and after receiving their performance feedback and attributional feedback. 
Results of this experiment partly supported the cognitive component of attribution theory. As predicted, it was found that stable attributions for own, actually experienced failure cause a lower expectation of success, compared to unstable attributions for failure. The predicted reverse effect after success, however, was not found. Attributing success to unstable causes did not lead to lower expectations of success than attributing success to stable causes.

Analyses of the behavioral measures revealed no support for the hypotheses. Two possible explanations for finding the cognitive effects and not finding behavioral effects will be discussed. First, it may very well be that, on the cognitive level, attributional information is taken into account, but when it comes to behavior, other variables (e.g. boredom, motivation, fatigue, emotions, ability) obscure the attributionally-caused differences. Second, attributions were manipulated by simply stating the causes of the alleged performances. Manipulation checks showed that these manipulations, although significant, were not particularly strong. A more convincing induction of attributions might have led to the predicted effects on a behavioral level.

In order to test this latter explanation, a similar experiment (see chapter 3, experiment 2) was performed, in which the attributional manipulations were strengthened. Whereas in the previous experiment subjects were simply told what had caused their success or failure, in this experiment much more extensive manipulations were used. Subjects were informed that, on the task they had to perform, the main causes of success or failure were ability, effort, task difficulty and luck. They were, furthermore, led to believe that electrodes attached to their wrist, and psychological tests had determined their effort expenditure and ability. It was said that task difficulty varied across subjects and was recorded as well. Correlations, supposedly based on previous sessions, were presented between these three variables and performance. Depending on the experimental condition a specific correlation pattern was shown: high correlations between the cause of the subject's attribution condition and low correlations for the other two causes. On the basis of these deceptions subjects were told that, according to the information provided by these measures, they had (not) worked hard enough, had a low (high) ability or had made very difficult (easy) tasks. Attributing to luck was manipulated by excluding ability, effort and task difficulty as causal factors. Because none of these factors correlated with task performance the only obvious cause left was luck.

Analyses of the data of this experiment again strongly supported the stability - expectation of success relation hypothesized in attribu- 
tion theory. As in the previous experiment this was true for failure only, after success the differences were in the predicted direction but failed to reach significance.

No support was found for the hypothesis that effort attributions cause higher persistence and performance after failure. Thus, again, the predictions of attribution theory on the behavioral level were not confirmed.

Because attributions were manipulated, and expectation of success, persistence, and performance were measured, the data of this experiment provide an opportunity to test the cognitive component of the attributional model. Correlational data after failure clearly show that differences in both stability and controllability are related to expectation of success. Whereas attribution theory predicts a relation between stability and expectation of success, the theory does not put forward a relation between controllability and expectation of success. After success this relation between controllability and expectation of success was absent:

However, another interesting pattern of correlations was found in the success condition. Attributing to controllable causes was found to lead to fewer correct responses after success. Internality was positively related to the number of incorrect responses and to persistence. Stability, finally, was negatively related to persistence after success. It seems as if subjects who feel they have proven themselves, that is, subjects who attribute their successful performance to internal, stable and controllable causes, are less motivated to succeed a second time.

Up to this point none of the experiments reported found the predicted positive effects of effort attributions on behavior. Earlier in this overview it was suggested that the complexity of the task might mediate the effectiveness of effort attributions for failure with respect to performance. On the basis of social facilitation theory it was predicted that effort attributions would have a positive effect on performance on simple tasks, but a negative effect on performance on complex tasks. An alternative hypothesis formulated on basis of the combination of attribution and social facilitation theory predicted that the more intense emotions associated with attributing failure to effort would counteract the positive effects of higher expectation of success and heightened persistence on complex tasks. Extending this argument implies that in the experiments discussed until now, showing only effects on the cognitive level, complex tasks have been used. If less complex tasks would have been used; the benefits of attributing failure to effort might have been found on a behavioral level as well.

Based on the first study of this thesis it might be concluded that other attributions do not have this detrimental effect. Secondlary 
analyses of the data obtained in this study revealed that the combined attribution of task difficulty and effort was more strongly associated with enhanced performance than an attribution to effort alone. This result led to the hypothesis that the combination of effort and task difficulty leads to smaller adverse emotional effects and thus better performance. The task difficulty component of the attribution might serve to ward off the effects of strong emotions, while the effort attribution might elicit enhanced investment of effort at a similar task in the future.

Considering the results of this first study a comparison between attributing to the combination of task difficulty and effort, effort alone and task difficulty alone seems warranted. In the final experiment (see chapter 4) subjects were induced to attribute their failure on either easy or complex tasks to effort, task difficulty or the combination of both. As in the previous experiments expectation of success and task behavior served as dependent measures. Emotions were measured as well, enabling tests of both the cognitive as well as the affective component of the attributional model.

Results of this experiment support Weiner's predictions, rather than the social facilitation hypothesis. In general, as predicted by Weiner, it is found that effort attributions lead to the largest increment of performance compared to the combined attribution and the task difficulty attribution. The combined attribution, in turn, leads to a larger performance increment compared to the task difficulty attribution. Inspection of separate levels of task difficulty, though, suggests that the main performance effect is due to an effect on easy tasks. This suggests that paying attention to the thoughts expressed by Kahneman, when looking at attribution theory, has some merit. Recent work of Cervone, Jiwani and Wood (1991; see also Bandura \& Wood, 1989; Wood \& Bandura, 1989), supports this thought. Cognitive strategies, in this case goal setting strategies, were more effective for easy compared to complex decision making performance.

With regard to expectation of success and persistence it may be said that, just like performance, differences are found after easy, but not after complex tasks. An attribution to effort or the combined attribution leads to a higher expectation of success and persistence than an attribution to task difficulty alone.

All concepts from the attributional model were either manipulated or measured, enabling tests of the complete attributional model. Inferences about the mechanisms by which effort attributions for failure have their beneficial effects may thus be made. As the previous discussion showed that attributional effects were small or 


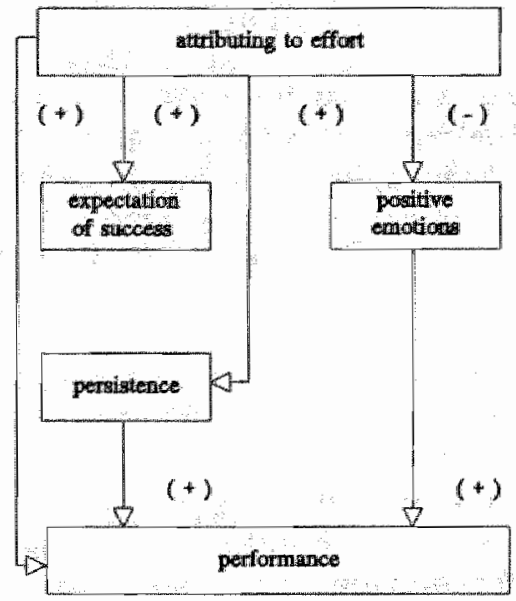

Figure 4. Results of regression analyses. A plus sign indicates a positive relation, a minus sign a negative relation ("Attributing to effort" represents the attribution manipulation: $1=$ task difficulty, $2=$ combined attribution, $3=$ effort).

absent after subjects made complex tasks, only the results with regard to easy tasks will be presented. Figure 4 summarizes these results.

As can be seen when comparing Figure 4 with Figure 2, the results of this experiment fit reasonably within attributional theory. Two major discrepancies are found. Instead of a relation between expectations of success and persistence, a direct link between attributions and persistence is found. Furthermore, an unpredicted direct link is found between attributions and performance. The relations between attributions on the one hand and expectancies of success, and emotions on the other hand, as well as the relations between persistence and emotions with performance, fit in with the predictions of attribution theory.

On the basis of this study, it may be concluded that the beneficial effect of attributing failure to effort consists of three separate effects. First, and most important, there is an effect of attributions on performance via persistence. Second, there is a negative effect of effort attributions via emotions on performance and, finally, there is a direct effect of attributions to effort on performance. Because differences in 
persistence are already accounted for, this direct effect of attributing to effort can only be interpreted by assuming that subjects in the effort condition improve the quality of their performance compared to subjects in the other conditions. Thus, subjects who attribute their failure more to effort concentrate harder. Attributing failure to the combination of effort and task difficulty leads to a similar expectation of success and persistence as attributing failure to effort. These conditions, however, differ from each other with regard to performance: an attribution of failure to effort leads to higher performance than an attribution of failure to the combination of effort and task difficulty. This might be due to subjects concentrating less in the combined condition.

The effect of positive emotions on performance deserves discussion as well. It should be noted that this effect is only present if the effect of differences in persistence is already accounted for. Whereas positive emotions and persistence both correlate positively with performance, they are negatively related to each other. Attributing failure to effort seems to lead to both a higher persistence and less positive emotions. It should be noted, however, that this negative effect of an effort attribution on performance via emotion, is much weaker than the persistence and concentration effect. The hypothesis that the emotional effect would balance the cognitive effect receives no support: an effort attribution after failure seems best after all.

However, considering Weiner's (1986) statement that if the situation becomes less artificial, emotions become more important, the arguments presented by Clifford $\left(1986^{\mathrm{a}, \mathrm{b}}\right)$ about the possible negative effects of attributing failure to effort should not be ignored.

\subsection{General discussion}

In the introduction to this overview it was stated that this thesis was concerned with three objectives. First, the assumptions of reattribution training about the causes to which people should attribute in order to achieve the best effects on cognitions and performance, were to be examined. Second, attention was to be paid to whether or not the positive effects of reattribution training are due to the specific content of the attributional change or of the attributional process itself. The third objective of this thesis was to provide some insights into the conditions under which attributions to effort lead, or do not lead to better performance. After presenting the theoretical rationale and results of the experiments it is possible to look back at these questions and provide some tentative answers. 
The main conclusion of this thesis must be that the ideas underlying reattribution practice, as well as attribution theory, receive support. However, support is not particularly strong and results are not always consistent with each other. Attributions do influence, as predicted, cognitions, emotions and to a lesser extent behavior of people. As has been shown in other attribution studies, expectations of success about behavior to be performed, are related to stability of attributions made for previous, comparable, behaviors. The experiments reported in this thesis add an important, critical facet to this body of knowledge. Since causal dimensions have been manipulated it may be concluded that differences in stability of attributions cause differences in expectations of success after failure.

Results with regard to behavioral and performance variables are less clear. The final experiment suggests that effort attributions for failure lead to better performance than task difficulty attributions alone or attributions to both task difficulty and effort. Results furthermore indicate that task characteristics determine the impact of attributional interventions on cognitions, behavior, and performance, and the process of seeking causal explanations may have a positive effect on performance in itself.

Two additional findings, not directly related to the main objectives of this thesis, deserve some consideration as well. A salient and consistent finding in this thesis is that the intensity of effects highly differs between success and failure situations. The experiments reported have shown no effects of attributions on any dependent variable after success. Differences have been in the predicted direction but never reached significance. Examining why people make attributions may provide some tentative answers to this phenomenon. Kelley $(1967,1972)$ states that people make attributions to understand, organize and form meaningful perspectives about the events happening to themselves and others. Weary et al. (1989) use the term control motivation to describe this urge or need people have. This line of reasoning seems to be supported by studies showing that unexpected information (Pyszczynski \& Greenberg, 1981, 1987; Wong \& Weiner, 1981) and negative outcomes (Weiner, 1986) stimulate attributional analyses. Unexpected information, as well as negative outcomes may be thought of as situations constituting instances in which people need control. It has also been shown that if the importance of the outcome or the involvement of the perceiver is enhanced, people engage more in attributional analyses (Berscheid, Graziano, Monson. \& Dermer; 1976). Taking these results into account, it seems reasonable to assume that after experiencing success, subjects are less inclined to make attributions. After failure people already think about attributions, which might render the attributional message more 
interesting to consider than after success when one is not spontaneously inclined to think about causes. Tentatively one may say that when success is expected or not especially important, attributions will not be elicited. Under these conditions attributional messages probably have low impact and do not result in cognitive or behavioral change.

Another result which was repeatedly found in the studies reported in this thesis is the relation between cognitive variables and attributions to controllability. Although attribution theory states that controllability of attributions is not related to expectation of success or persistence, both experiment 2 and 3 found those relations. These results indicate that expectation of success and persistence are influenced by variables other than stability. In a sense this is intuitively plausible; instability implies the possibility of change, but not whether or not this change will be beneficial. Controllability, though, implies control over the direction of change.

Translating these results to interventions should be done with caution. Subjects in these studies were all college students in their first year, and generalization of these results to other populations must be done with considerable care. The robustness of attributional effects across different populations, found in other research paradigms, permits some optimism that experiments with different populations might lead to similar effects (see Weary et al. (1989) or Weiner (1986) for an overview).

A more problematic point might be the artificial, experimental situation used. Although care was taken to ensure that all subjects valued the tasks as being important and were involved in their work, the situation is still different from, for example, failing an exam, not making the football team or being turned down for a date.

In the experiments reported here, tasks were chosen with which subjects had no experience and on which they would find it difficult to predict their scores, in order to be able to provide them with credible (false) feedback about their performance. In real life situations, however, people generally have some experience with the task they face. Someone who tries to quit smoking or lose weight in many instances tried to achieve this goal before. Changing the ideas this person has about what caused previous failures will not be easy.

Thus, simply telling people who have multiple failure experiences with behavior like weight loss or quitting smoking that they should attribute their previous failures to lack of effort and try a little harder at the next attempt will not succeed. Relapse prevention (Marlatt \& Gordon, 1985), Rational Emotive Therapy (Ellis, 1962), theories of depression (Beck, 1976) and recent work on "Health Counseling" 
(Gerards \& Hospers, 1991) provide suggestions on how reattribution techniques may be incorporated in broader interventions (see Den Boer, Kok, Hospers, Gerards \& Strecher, 1991; Kok, Den Boer, De Vries, Gerards, Hospers \& Mudde, in press).

Finally, it may be suggested that, in applying attributional techniques, care should be taken to look carefully at the tasks at hand and the capabilities of the target population. Telling people they should try harder on a task where achievement is not dependent upon effort, or without providing them with the tools or skills needed, probably will not make them lose weight, stop smoking, stay in school or attain better grades. The evolution and evaluation of health education interventions has shown that people need help in order to change their behavior. Providing opportunities by means of structural measures might lead to behavioral change. It is clear that promoting safe sex, without providing the opportunity to buy condoms, or instituting a weight loss program without making low-fat products available, will have sub-optimal results.

At this point it is possible to formulate the main theoretical and practicall conclusions this thesis has led to. In general, the experiments have shown the ideas of Weiner and reattribution practice to be valid. The idea, that making people attribute their failures to effort has beneficial effects on cognitions, behavior and performance, recelves support. To some extent this seems to be due to encouraging subjects to think about causes, but also to a heightened persistence and concentration. The only significant deviation from attribution theory is that no attributional effects after success were found. In case of a complex task or situations when less positive emotions are evoked the effectiveness of effort attributions, seems to be reduced. It should be clear, however, that this does not lead to negative effects of attributing failure to effort. The relation between controllability of attributions and expectation of success, that were consistently found, seem plausible, and it may be useful to incorporate this relation in attribution theory. 


\section{Chapter 2}

\section{Measurements Effects in Reattribution Research ${ }^{1}$}

\section{Abstract}

In studies investigating the effects of reattribution training, reattributing to effort is confounded with forcing subjects to think about causes of their performance. An experiment was conducted to investigate the effects on performance of having people think about causes of outcomes by means of measuring attributions for success or failure. The results indicate that measurement has a beneficial effect on performance after failure. Measurement of attributions after success does not affect performance or may even slightly deteriorate it. Explanations for these results are discussed.

\subsection{Introduction}

Reattribution training aims at changing people's behavior by changing their attributions. Over the last few decades training of this nature has been developed for a considerable range of problems, such as weight management (Haisch, Rduch \& Haisch, 1985), reading skills below grade level (Fowler \& Peterson, 1981) and persistence at an experimental task (Andrews \& Debus, 1978; Medway \& Venino, 1982). All these studies are based on attribution theory (Weiner, 1986) in which a relationship between attributions people make and behavior is proposed. Because of this relationship, reattribution training assumes that a change in attributions will restilt in a change of behavior. In a review of studies in which the effects of reattribution prom grams have been investigated, Fórsterling (1985) concludes that attributing failure to a lack of effort results in a higher subsequent persistence and performance than attributing failure to stable factors, like ability. After success, effort or ability is supposed to be the attribution resulting in the highest persistence and performance, though this prediction has not received a lot of empirical attention.

${ }^{5}$ Published as: Den Boer, D.J., Meertens, R.M., Kok, G.I., \& Van Krippenberg, A.F.M. (1989). Measurement effects in reattribution research. European Journal of Social Psychology, 19, 553-559. 
The dominant research design in this kind of study is a comparison between subjects who receive attributional training and subjects who do not receive this training. Attributional training teaches subjects to attribute their failure to a lack of effort and their success to the sufficient amount of effort invested in the task. Manipulated attribution is considered to be the cause of any behavioral or cognitive changes that occur after the training. However, a comparison between subjects who are pressed to attribute to effort and subjects who are not pressed to do so, is confounded with the fact that subjects who have received attribution training are forced to make a much more explicit causal search than subjects in the control condition. They not only have to consider whether the information the experimenter gives them about the reasons (e.g. effort) for their success or failure is correct, but, at least in the studies mentioned above, they also have to complete several attributional questionnaires to check whether or not they really attribute as intended by the experimenter. Completing an attribution questionnaire forces the subjects to make an explicit causal search. The causal dimension scale (Russell, 1982), for instance, asks subjects whether a cause is internal or external, stable or unstable and controllable or uncontrollable.

It is questionable whether subjects would ever ask themselves such questions spontaneously. Fiske and Taylor (1984, p. 96) state that "Evidence that people go through the kinds of complex causal analyses that attribution researchers impute to them is rare, ...". A study by Pruitt and Insko (1980) shows that subjects report thoughts of an attributional nature in only $33 \%$ of the cases. Thus, explicitly asking subjects about attributions, as is done in reattribution studies, will often change the subject's train of thought. Making attributions provides one with the possibility of prediction and control (Kelley, 1967), giving one the opportunity to consider what can be done to replicate or avoid the previous experience with the task at hand. Besides obtaining information about causes they would normally seldom consider, the attributional measures indicate causes to people which they do not think of themselves. Having subjects who fail or succeed think about attributions makes them consider in a systematic way why they failed or succeeded. This gives them the opportunity to make a realistic estimate of what went right or wrong. If they would act according to that information, measuring attributions, may be expected to have a positive effect on performance.

The aim of the present study is to examine whether the effects of attributional retraining programs can partly be explained by the informational processes which are elicited by answering questions about causal attributions. Thus, our primary concern is with how the measurement of attributions for task performance per se affects subse- 
quent performance on a related task, while it is only of secondary concern whether there is a special intervening role for effort attributions in the measurement condition. Success or failure on a task and presence or absence of attributional measures were independently manipulated in a $2 \times 2$ factorial design.

\subsection{Method}

The subjects in this study $(N=55)$ were students of the University of Limburg (The Netherlands). Each subject received a small sum of money for his/her participation. Upon arrival they were told that the experiment was aimed at validating a test. The test was supposedly designed to measure an important skill, namely "lateral thinking". The rest of the experiment was fully explained on paper. Subjects had to complete two tasks, the first consisting of 30 anagrams, the second of one 15-letter word, from the letters of which the subjects had to construct as many other words as possible. The time limit for the first task was 2 minutes and for the second 20 minutes (on the second task subjects could quit before the time limit was reached), after which the experimenter collected the questionnaires and left the room to "compute their scores". A second experimenter stayed behind to ensure that subjects did not talk to each other. After approximately 5 minutes the experimenter returned with the scores of the subjects. Each subject received either the score 27 (out of a possible 100) or 83 . This score had no relation to the subject's true score. At this point in the experiment half of the subjects had to fill in a series of 20 questions about the cause of their outcome. Twelve of these questions were constructed in accordance with Russell's (1982) causal dimension scale. Four questions asked about the degree to which ability, effort, task difficulty and luck had led to their outcome on the task. "The questionnaire further asked how able they thought they were, how much effort they had invested, how difficult the test had been and to what degree luck had played a role in obtaining their outcome. The other half of the subjects had to make the same number of questions, about a topic totally unrelated to attributions (liking of different colors). Subsequently it was announced that subjects had to complete a different version of the task. After subjects had indicated how important it was to them to obtain a good score, they made the second task. The order of tasks was balanced. After all the subjects had finished with the second set of tasks, the experimenter debriefed the subjects and explained the purpose of the experiment.

The dependent measure in this design is performance. This variable was measured by computing the true score of the subjects at each of the tasks. 
Table 1. Distribution of perfomance scores (trans-formed) over the cellmeans.

\begin{tabular}{lcc}
\cline { 2 - 2 } & $\begin{array}{c}\text { Measurement of } \\
\text { attributions }\end{array}$ & $\begin{array}{c}\text { No measurement } \\
\text { of attributions }\end{array}$ \\
\hline Success & $-0.25^{\mathrm{b}}$ & $0.19^{\mathrm{ib}}$ \\
Faillure & $0.70^{\mathrm{b}}$ & $-0.56^{\mathrm{a}}$ \\
\hline
\end{tabular}

Note: Means in cells with different letters differ at the $5 \%$ significance level.

\subsection{Results}

The outcome manipulation was checked by asking the subjects how good or bad (5-point scale; $1=$ a very bad score, $5=$ a very good score) they thought the score they had received was. An ANOVA, with this variable as the dependent measure, showed that subjects getting failure feedback perceived their outcome as a bad score $\left(M_{d(j f f e r e n c e)}=1,48\right)$ while subjects getting success feedback perceived it as a good score $\left(M_{d}=4.23, F(1,51)=220.26, p<.001\right)$. This result indicates that subjects perceived their scores as intended.

Firstly the performance scores on the different tasks were transformed into $z$-scores. On the basis of the different $z$-scores for the anagram task and the 15-letter task an overall performance score was computed per subset of tasks. Subsequently difference scores for performance on the first set of tasks and the second set of tasks were computed. Subsequent analyses use this measure as dependent variable. A positive score indicates an increase in performance over the two sets of tasks; a negative score a decrease in performance.

An analysis of variance with performance as dependent variable revealed an outcome $x$ measurement effect on the performance measure $(F(1,51)=4.16, p<.05)$. This interaction is presented in Table 1 . Measurement of attributions after failure causes people to perform better on a subsequent task, while people who do not fill in a questionnaire perform worse on a subsequent task. As can be seen in table 1 the difference between these two means is significant $(F(1,51)=4.57$, $p<.04$ ). After success the effect of the presence or absence of attributional measures seems to be reversed. Subjects who are questioned about attributions after success score worse on a subsequent task $\left(M_{d}=-.25\right)$, while people who are not bothered about attributions score better on the second set of tasks $\left(M_{d}=.19\right)$. The simple effect of the measurement factor within success however is not significant $(F(1,51)=.62, p<.45)$. The main effects of the factors outcome and measurement did not reach significance. 
Table 2. Within cell correlations, for success and failure separately, between attributions subjects make and their performance.

\begin{tabular}{|c|c|c|c|c|c|c|c|c|}
\hline & \multicolumn{5}{|c|}{ After success } & \multicolumn{3}{|c|}{ After fallure } \\
\hline Ability & & & & & & & & \\
\hline Effort & 0.26 & & $\therefore$ & & 0.16 & & & \\
\hline $\begin{array}{l}\text { Taskdiffi- } \\
\text { culty }\end{array}$ & -0.19 & -0.30 & & & 0.12 & $0.71^{*}$ & & $\because$ \\
\hline Luck & -0.36 & 0.31 & 0.33 & & -0.12 & -0.28 & $-0.52^{*}$ & \\
\hline \multirow[t]{2}{*}{$\begin{array}{l}\text { Perform- } \\
\text { ance }\end{array}$} & -0.19 & -0.34 & 0.04 & 0.21 & 0.31 & 0.32 & $0.67^{*}$ & -0.49. \\
\hline & A & $\mathrm{E}$ & $\mathrm{T}$ & $\mathrm{L}$ & $\mathrm{A}$ & E & $\mathrm{T}$ & $\mathrm{L}$ \\
\hline
\end{tabular}

$p<.05$

To gain some insight in the intervening role of attributions on performance the data of the measurement condition were further analyzed. Table 2 contains the within cell correlations between the variables measuring how much subjects attributed their performance to a certain task and the subsequent change in their performance. After success we find no significant correlations between the variables. After failure, however, attribution to task difficulty is positively related to attribution to effort and to the performance measure, while attribution to luck is negatively related to the measure of performance.

\subsection{Discussion}

The results indicate that the effect of measuring attributions depends on whether success or failure feedback was given. It seems that people who fail, profit from an explicit causal search; they perform better than people who are not systematically asked about their causal perceptions after failure. This means that the effects of attributional change programs can, at least partly, be explained by the measurement of attributions. Contrary to what we predicted we did not find a beneficial effect of measuring attributions after success. The (nonsignificant) difference we found is even in the opposite direction. 
Further within cell analyses did not reveal any significant correlations within the "measurement/success' condition. We did find, however, that subjects attributing their low first performance to task difficulty subsequently achieve a higher score than subjects who attribute less to task difficulty. Attributing to luck seems to have a negative impact on performance: The more subjects attribute their first performance to luck the more their second performance deteriorates.

One way to explain the positive effects on performance of measuring attributions after failure is that subjects, given that they consider the task at hand important, are more strongly motivated to perform better after failure than after success (cf. Festinger, 1954; Rijsman, 1980). In the 'no attribution measurement' condition, where the subjects' attention is distracted from the task to a totally unrelated questionnaire, they might judge the task as less important. Therefore, subjects are less motivated to improve their performance after failure in the 'no measurement of attribution' condition, compared to the 'attribution measurement' condition. However, there turns out to be no difference in the importance subjects attached to the achievement of a good result on the second task between "attribution measurement' and 'no attribution measurement" conditions $(F(1,51)<1)$.

Another tentative explanation for the effect of attribution measurement in the failure condition is that the request to answer explicit questions concerning attributions may have evoked more effort attributions than subjects would generate spontaneously. These effort attributions might, in turn, induce subjects to try harder on a subsequent task. This line of reasoning assumes a significant correlation between effort attribution and performance improvement in the 'failure/attribution measurement' condition. The observed correllation between effort and performance improvement was, however, small and non-significant $(r=32, n s)$.

The observed correlations between attributions and task improvement in the 'failure/attribution measurement" condition suggest, however, a somewhat related process with slightly different psychological implications. As shown in Table 2 above, there is a substantial positive correlation of performance improvement with attribution to task difficulty $(r=.67, p<.05)$, and a negative correlation of performance improvement with attribution to luck $(r=-.49, p<.05)$. These results may, in our view, be interpreted as follows: the explicit measurement of attribution may have evoked a relative high level of task difficulty and low level of luck attributions in the failure condition (as compared to the failure condition without attribution measurement). Attribution of failure on the first task to task difficulty may have elicited subjects to recognize that they should invest more effort in the second task in order to succeed, while subjects attribution of failure 
on the first task to (the absence of) luck - which is a non-controllable causal factor - may have discouraged them from investing more effort in the second task. The observed correlations do support this interpretation.

It may be argued that the causal chain 'failure $->>$ attribution to task difficulty $\rightarrow>$ increased effort on second task $\rightarrow>$ performance improvement' comprises a more face-saving subjective inter-pretation of the first performance than a 'failure --> effort attribution" sequence, because the latter implies personal responsibility and, possibly, concomitant guilt with regard to the initial failure (cf. Clifford, 1986, $6^{\mathrm{a}, \mathrm{b}}$; Weiner, 1986; Wilson \& Linville, 1982, 1985). The fact that, nevertheless, lack of effort is implicitly conceded may be derived from the substantial correlation between the task difficulty and effort attribution $(r=.71, p<.05)$.

The above explanation seems capable of explaining attribution measurement effects in the failure condition. A comparable effect of attribution in the measurement after success was not observed (at best, there was a non-significant tendency in the opposite direction). This differential effect of attribution measurement in success and failure conditions may be due to the greater need people experience after failure to understand the causes of their performance (Bohner, Bless, Schwarz \& Strack, 1988). After failure, the structure provided by the attributional measures might fill a gap and lead to more cognitive processing and stronger effects on behavior than the same attributional enquiry after success.

Our post-hoc explanations seem to be capable of explaining the performance effects observed in this study while taking into account the correlations of performance increment with the attributions provided by the subjects in the "attribution measurement" conditions. Although further research is needed to corroborate our explanation, it may already be concluded that attribution measurement as such probably affects the nature of subjective attribution processes as well as subsequent task performances. 


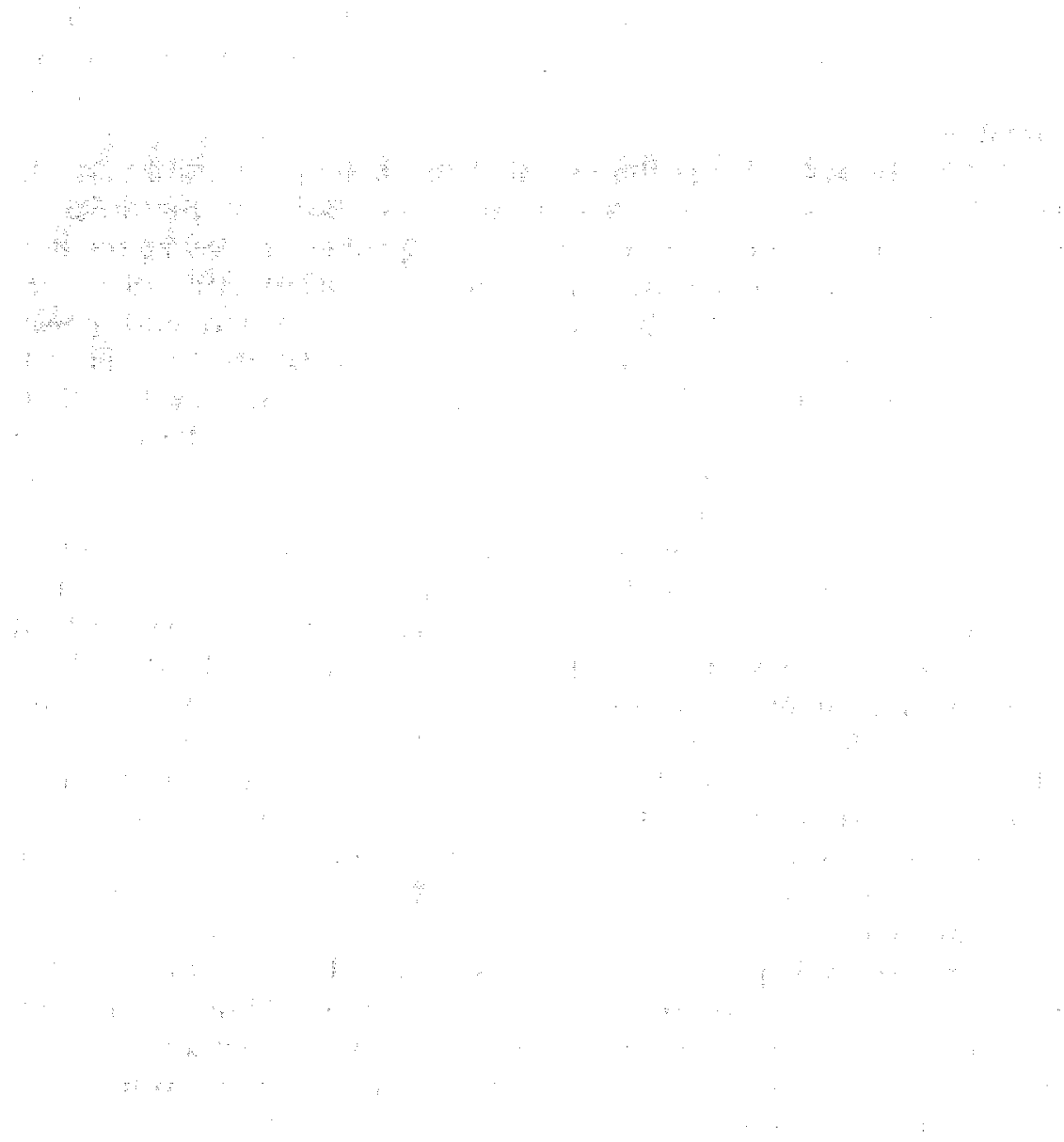




\title{
Chapter 3
}

\section{Effects of differences on attributional dimensions on cognitions and behavior ${ }^{1}$}

\author{
Abstract
}

Weiner's attribution theory $(1985 ; 1986)$ describes relations between attributions people make, their expectation of success and behavior. Two experiments, designed to test the causal structure of these relations, are reported. After subjects performed a task, they received (bogus) success or failure feedback and were induced to attribute their performance to effort, ability, luck or task difficulty. Subsequently they performed a different version of the same task again. Results of both experiments revealed that, after failure, attributions to stable causes influenced expectations of success. After success, however, differences in attributions to stable causes did not lead to differences in expectations of success. Finally, in experiment 2, some support was found for the hypothesis that different attributions cause differences in persistence and performance, as predicted by attribution theory.

\subsection{Introduction}

In reattribution studies (Försterling, 1985, 1988) it is attempted to change people's behavior by changing the attributions they make for previous outcomes. Based on attribution theory, as formulated by Weiner $(1985,1986)$, people are induced to attribute their previous failures to a lack of effort. Successful applications of this approach may be found in many different problem areas (Den Boer, Meertens \& Kok, 1989; Försterling, 1985; Weary, Stanley \& Harvey, 1989). Chapin and Dyck (1976) and Fowler and Peterson (1981), for instance, succeeded in improving reading skills of children. Others have managed to improve arithmetic skills of children (Dweck, 1975; Schunk, 1982, 1983, 1984), or performance of subjects on anagram tasks (Andrews \& Debus, 1978). The induction of the effort attribution, which

${ }^{1}$ Submitted for publication as: Den Boer, D.J., Meertens, R.M., Kok, G.J., \& Van Knippenberg, A.F.M.. Effects of differences on attributional dimensions on cognitions and behaviour. 
constituted the experimental intervention, is generally held responsible for the change in performance. In this article we will try to gain some further insight in the mechanisms by which these interventions lead to performance improvements.

Attributing failure to lack of effort is supposed to enhance expectations of success and therefore, to a continued persistence on the task and superior subsequent performance (Försterling, 1985; Weary et al. 1989). The reason why effort has been selected as the most appropriate attribution for failure is that it is generally perceived as an unstable (i.e. it may change over time), internal (it is something which is a part of the attributor and not of the environment) and controllable cause (it is under voluntary control of the attributor). These characteristics of effort attributions are supposed to contribute to the subjects' perception that, having experienced failure, they do not necessarily have to expect failure on future occasions.

Within the reattribution paradigm, comparisons tend to be made between pre- and post-measures of performance (e.g. Dweck, 1975) or between experimental and control groups (e.g. Anderson, 1983). As far as we know there have been no attempts, within the reattribution paradigm, to compare attributions which differ on the dimensions of stability, intemality and controllability. Hence, exactly which (combination of characteristics of the effort attribution are exactly responsible for the observed change in performance cannot be determined on the basis of the existing reattribution studies (see Den Boer, Meertens, Kok \& Van Knippenberg, 1989).

The specific attribution theory on which reattribution studies are based (Weiner, 1985, 1986), is concerned with the relations between attributions, their dimensionality, the accompanying emotions, expectations of success and behavioral variables. Closer inspection of Weiner's theory may yield a more precise assessment as to which components are responsible for the beneficial effects of reattribution studies. A great variety of causes may be used to explain the events people encounter. As suggested above, these causes can be classified on three dimensions: internality, stability and controllability. Because the conceptual status of this last dimension, controllability, has proved to be, theoretically as well as empirically, somewhat questionable (Hewstone \& Antaki, 1988; Weiner, 1986, pp. 66-72), our present discussion will be confined to the dimensions internality and stability.

Weiner (1986) proposes a relation between the causes perceived for success or failure and the way people deal with a similar task at some later time. Part of the theory is concerned with the causal relation between perceptions of stability, expectations of success and behavior of the attributor. Attributing success to stable causes will 
lead to higher expectation of success compared to attributing success to unstable causes, while after failure this effect is reversed: stable attributions for failure are supposed to lead to lower expectations of success than unstable attributions for failure. Weiner argues that people who have a high expectation of success, invest more energy in the task at hand than people who have a low expectation of success. In the latter case, that is when one does not expect to succeed, there seems to be little reason to invest energy in the task.

Support for this first step of the theory is overwhelming. Correlational studies (e.g. McMahan, 1973; Weiner, Nierenberg, \& Goldstein, 1976) and studies which use vignettes (hypothetical situations, e.g. Neale \& Friend, 1972) clearly demonstrate the hypothesized relation between stability of attributions and expectations of success (see Weiner, 1986, pp 85-95 for an extensive overview). These findings suggest that the reported effects of reattribution studies are entirely due to the fact that the effort manipulations used imply causal instability. Therefore one might expect other unstable attributions to result in the same or similar effects. Research by Wilson and Linville $(1982,1985)$ supports this line of reasoning. These authors induced subjects to attribute their previous poor performance to "unstable task difficulty" (besides being unstable, this cause was also presented as uncontrollable and external). In accordance with our present argument, this manipulation indeed resulted in an improved task performance.

There are, however, some problems with the conclusion reached above that need to be addressed. In the first place, results based on correlational or vignette studies are generalized to causal effects of attributions in situations in which subjects personally experience failure. We know of only two studies (Kernis, Zuckerman \& McVay, 1988; Riemer, 1975) in which attributions for own performance have been manipulated and in which the effects on subsequent expectation of success and/or behavior change have been measured. Riemer's study, which was concerned with attributions after success, failed to support the proposed stability-expectation relationship. This might have been due to the combination of the task (piano playing) and the attribution presented. Weiner (1983) argues that if piano playing is presented as an ability, as Riemer did, an attributional effort manipulation is not likely to be successful. The study by Kernis et al. (1988), which focused on the role of differences in internality of attributions after success, is of less interest here, since it does not pertain to the postulated stability-expectation-behavior relationship. Therefore, specifically for the domain of attributions made for own actual success or failure and its consequences, there is not much experimental research to go on. 
Attention should, furthermore, be paid to the question of how differences in stability of attributions result in differences in behavior. On the basis of attribution theory, one would expect that differences in stability of attributions influence expectations of success, which in turn influence persistence. Differences in persistence, finally, should result in differences in performance. Correlational studies (e.g. Hospers, Kok \& Strecher, 1990) support this explanation. A second possibility, however, is that stability of attribution influences expectation of success and behavior, without a (direct) causal link between these latter two variables. Until now only the relation between stability and expectation of success and behavior has been discussed. Weiner's theory suggests, however, that internality (e.g. Kernis et al., 1988) and controllability also affect behavior (Weiner, 1986, p, 240), indirect via emotions. Although the primary focus of this article will be on the stability-expectation-behavior link some attention must be paid to this issue. According to attribution theory differences in controllability and internality should affect behaviorall variables as well.

In summary it will be assumed that the beneficial effect of reattribution studies are due to attributing failure to unstable causes. In line with attribution theory we predict stable attributions for failure to lead, via a lower expectation of success, to less persistence and poorer performance compared to unstable attributions for failure. After success we hypothesize this relationship to be reversed: unstable attributions for success lead, via a lower expectation of success, to less persistence and poorer performance than stable attributions for success. It is furthermore hypothesized that internality and controllability of attributions affect persistence and performance. Although there has not been much research in this area some tentative predictions can be made. It will be assumed that, irrespective of result, the more internal and/or controllable attributions are, the more persistent subjects will be and the higher their performance.

In order to investigate these hypotheses two experiments have been conducted in which performance of subjects (success vs. failure) and internality and stability of attributions (effort, ability, task difficulty or luck) were independently manipulated. Controllability of attributions has been measured. Apart from manipulation checks, expectations of success and task behavior were measured.

\subsection{Method experiment 1}

Subjects. One hundred and three (103) undergraduate students of the University of Limburg (The Netherlands) participated in this experi- 
ment. Subjects were volunteers who responded to an advertisement in the university newspaper. For their participation each subject received 15 Dutch guilders (approximately $\$ 7.50$ ). Mean age of subjects was 20.5 years.

Design and procedure. The design of this study was a 2 (success vs. failure) $\times 2$ (internal vs external attributions) $\times 2$ (stable vs. unstable attributions) factorial design. Main dependent variables were expectation of success, persistence, and performance.

Subjects, arriving in groups of at most 12 , were seated in separate cubicles after receiving a brief introduction. All further instructions were given on paper. The study was labelled as an attempt to develop a test capable of measuring the ability 'lateral thinking', which was described as the ability to solve problems in an unorthodox, alternative and creative way. The subjects were told that the ability involved was a very important one because some of the major Dutch companies were planning to use this test to select applicants for jobs. After these instructions subjects completed a task in which they had to make as many new words as they could out of the 15 letters of a given word. These new words did not need to contain all 15 letters. When subjects indicated their desire to stop, the amount of time elapsed since the start of the task was noted. This measure served as an index of persistence. To prevent the sessions from taking too long, there was a time limit of twenty minutes for this task. Considerable care was taken in devising and presenting the task in such a way that it was virtually impossible for subjects to assess how well or poorly they had performed.

After collecting the test forms, one experimenter left the room to 'compute the scores'. The other experimenter stayed behind to make sure that subjects did not talk among each other. At this point subjects had to indicate which score they expected to receive on the task (scale: 0-100). After about five minutes the experimenter returned with the scores of the subjects. On a random basis half of the subjects received 27 points out of the possible 100 (failure condition). The other half received 83 points (success condition). Feedback about these scores was accompanied by the remark that the score was either very low or very high.

Directly after this manipulation of the performance factor, subjects were told what had caused their success or failure. Depending on the condition, subjects received a text in which it was stressed that effort (internal/unstable), ability (internal/stable), luck (external/unstable) or task difficulty (external/stable) was responsible for their performance. Subjects were told that, because the experimenters had a lot of experience with these tasks, they knew what caused success or failure. 
Manipulation checks followed the feedback and attribution manipulation. First subjects had to answer the Dutch equivalent of the Causal Dimension Scale (Russell, 1982), which measures internality, stability and controllability of the cause they held responsible for their performance. In order to elicit active processing of attributional considerations, the subjects were asked "to think back to their previous results" and "try to determine what was, according to them, the cause of this success or failure". The performance manipulation was checked by asking subjects how high or low they perceived their score (5-point scale; 1 =very low, 5 =very high).

Measurement of the dependent variables followed immediately after the manipulation checks. Expectation of success was measured by asking subjects how well they expected to perform, if they had to do the same task, in a different version, again. Finally subjects actually did the same task, in a different version (order was counterbalanced), which yielded a second persistence and performance measure. After completion of the second task, subjects were debriefed and received their payment.

\subsection{Results and discussion experiment 1}

Manipulation checks. Manipulation of the performance feedback factor was checked by means of ANOVA with performance feedback, internality and stability as independent variables and perception of performance as dependent variable. This analysis showed a significant main effect of performance feedback only $(F(1,95)=507.23, p<.001)$. Subjects in the success condition perceived their performance as better $(M=4.27)$ than subjects in the failure condition $(M=1.41)$.

The internality and stability manipulations were checked by means of the subscales in the Causal Dimension Scale which represent the internality and stability dimensions (Cronbach's $\alpha$ respectively .82 and .66$)$. A $2 \times 2 \times 2$ ANOVA on the stability subscale revealed two main effects. Subjects in the success condition $(M=4.12)$ attributed their performance to less stable causes than subjects in the failure condition $(M=5.44, F(1,95)=6.95, p<.01)$. Furthermore, a significant main effect of stability was found. Subjects in the stable conditions attributed more to stable causes $(M=5.08)$, than subjects in the unstable conditions $(M=4.48, F(1,95)=6.93, p<.01)$. A similar ANOVA on the internality subscale also revealed two main effects. Subjects in the internal conditions attributed more to internal causes $(M=4.97)$ than subjects in the external conditions $(M=4.47, F(1,95)=$ $2.91, p<.05)$. Finally it was found that subjects in the success conditions attributed more to internal causes $(M=5.30)$ compared to those 
in the failure conditions $(M=4.14, F(1,95)=15.34, p<.001)$. It seems as if subjects impute their performance in a self-serving way (cf. Ross \& Fletcher, 1985).

Considering these manipulation checks, it should be emphasized that the responses of the subjects revealed that some form of subjective internalization of the manipulated attribution did take place. Whille the manipulation consisted of presenting subjects with concrete causes of their success or failure (i.e. effort, ability, luck and task difficulty), they appear to have appropriately translated these attributions in terms of the intended underlying dimensions of causality (i.e. internality and stability).

Table 1. Expectation of success as a function of manipulated performance feedback and stability of attributions.

\begin{tabular}{lcr} 
& Stable & Unstable \\
\hline Success & $0.84^{\mathrm{a}}$ & $0.36^{\mathrm{a}}$ \\
Failure & $-0.82^{\mathrm{c}}$ & $-0.40^{\mathrm{b}}$ \\
\hline
\end{tabular}

Note: Different letters indicate significant differences $\left(p_{\text {onesiditad }}<.05\right)$.

Expectations of success. Expectations of success measured before and after the manipulations were converted to $z$-scores and subsequently pre- to post-test change scores were computed. Pre-test expectations of success did not differ across the experimental conditions (all $F s<1$ ), nor were any significant interactions found. With the manipulation of internality and stability, controllability was varied as well, making it necessary to perform preliminary analyses testing whether or not differences between conditions were due to differences in controllability. A $2 \times 2 \times 2$ analysis of covariance with the controllability subscale as a covariate revealed a non-significant contribution of the covariate $(\beta=.18, p<.11)$ in the prediction of expectation of success. Effects of the manipulated factors are, thus, not due to differences in controllability.

A $2 \times 2 \times 2$ analysis of variance revealed a highly significant effect of the feedback manipulation $(F(1,78)=46.71, p<.001)$, reflecting the lower expectations of success of subjects in the failure $(M=-.61)$ compared to those in the success conditions $(M=.60)$. Aside from this main effect a significant interaction between the feedback and stability manipulation was found $(F(1,78)=3.97, p<.05$, see Table 1 , next page). As predicted, subjects who were led to attribute their failure to stable causes lowered their expectation of success more than subjects 
attributing to unstable causes $\left(F(1,78)=2.93, p_{\text {onesidet }}<.05\right)$. After success this effect was reversed but did not reach significance $(F(1,78)=$ $1.25, p<.27)$.

This result supports our hypothesis that stability of attributions is related to expectations of success. The non-significant difference between cells in the success conditions parallels the results of Riemer (1975). The absence of an effect in the success condition might reflect the fact that people are less inclined to make spontaneous attributions after success than after failure (Bohner, Bless, Schwarz \& Strack, 1988; Weiner, 1985). Subjects might be more sensitive to attributional information when they are already inclined to consider what caused their performance.

Behavioral measures. The persistence measure, time (in seconds) spent at the task, and the performance measure, number of correct responses, were transformed into $z$-scores, and pre- to post-test differences were computed. Again neither differences across conditions nor interactions were found at the pre-test (all $\left.F_{s}<1\right)$. Because preliminary analyses revealed no order effects $(F<1)$, this factor is ignored in the remaining analyses.

Neither a $2 \times 2 \times 2$ analysis of covariance with controllability as a covariate and the behavioral measures as dependent variables nor a similar $2 \times 2 \times 2$ analysis of variance revealed any significant effects. The predicted effects of internality nor the predicted interaction effect of the performance and stability manipulations were found. Considering that stability and internality are unrelated to persistence and performance, it makes little sense to test a causal model in which effects of attributional dimensions on behavioral variables are mediated by expectation of success.

Summarizing it can be concluded that, as predicted, stable attributions for failure lead to lower expectations of success than unstable attributions for failure. To our knowledge, this effect of stability on expectations of success has not been demonstrated before in a situation in which attributions for actually experienced failure have been manipulated experimentally. After success, however, the expected reverse relation (i.e. stable attributions enhance expectations of success), was not found.

On the other hand, though, we did not find the predicted attributionally caused differences in persistence and performance. The absence of effects on the behavioral level might be caused by several factors. In the first place, it could very well be that on the cognitive level subjects take attributional information into account, but other variables (e.g. boredom, motivation, fatigue, emotions, ability) ob- 
scure attributionally caused differences on the behavioral level. Secondly, attributions were manipulated by simply stating the causes of the alleged performances. The manipulation checks show that this manipulation, although significant, was not particularly strong. A more convincing induction of attributions might lead to the predicted effects on a behavioral level. This could be achieved by supplementing the verbal message with factual information supporting the subjective plausibility that the alleged cause had actually influenced performance. In terms of our present research paradigm, it may be argued that, if subjects are made to believe that the experimenter has information with regard to their ability, luck, effort and task difficulty, the experimenters claim that one of these particular causes is responsible for their performance would probably be more convincing.

Finally, it may be of interest to consider the nature of the task used in this experiment. It might very well be that attributional manipulations are effective only for certain kinds of tasks. One, obvious, factor would be the extent to which task performance depends on persistence. The more performance depends on differences in persistence, the more likely it is that attributional interventions cause differences in performance. It is probably ineffective to tell people to work harder when they do not feel or perceive their performance to be improved by increased effort allocation. Subjects, in the present experiment, might have believed performance on the word production task to be insensitive to enhanced effort expenditure. A more suitable task might be capable of producing attributional effects on the behavioral level.

With these considerations in mind, a similar experiment was carried out. Attributional manipulations and the experimental task were adapted along the lines discussed above. Again it is hypothesized that stability of attributions will affect behavioral variables (i.e. persistence and performance) via expectations of success. Stable attributions for failure are predicted to lead to lower expectations of success than unstable attributions. After success we expect a reversed effect: unstable attributions are predicted to lead to lower expectations of success than stable attributions. Bearing the results of the first experiment in mind, we also expect that this effect is much stronger after failure than after success (see also Den Boer, Meertens, Kok \& Van Knippenberg, 1989). Elaborating this argument for the relationship between stability and the behavioral variables, we expect stability of attributions to be negatively related to the behavioral variables after failure, while we expect a reversed relationship after success, i.e. a positive effect of stability of attributions on the behavioral variables. The latter effect is, however, probably weaker than the hypothesized effect of stability after failure. 
As argued in the introduction, it will again be hypothesized that, irrespective of result, the more internal and/or controllable attributions are the more persistent subjects will be and the higher their performance.

\subsection{Method experiment 2}

Subjects. One hundred and forty-two (142) subjects, all undergraduate students from the University of Limburg (The Netherlands), participated in this experiment. All subjects were volunteers who reacted to a call for participants in a laboratory study, during one of their classes. Mean age of subjects was 20.2 years. Subjects received 15 Dutch guilders $(\$ 7.50)$ for their participation.

Procedure. Whereas the first experiment was a paper and pencil experiment, subjects, arriving in groups of six, were now seated at a personal computer. Information about the experiment, manipulations and questions were given on the monitor and subjects recorded their answers by means of a keyboard. The aim of this experiment was presented as an investigation into the relation between the ability "alertness" and performance on a certain task. Alertness was described as the ability of being able to respond fast and adequate to unexpected situations.

First, subjects made a, supposedly, valid test to determine their alertness. This test consisted of three small sub-tasks of which previous research (Van Knippenberg, Wilke, \& De Vries, 1981) has shown that it is perceived by subjects as a valid and reliable test of alertness. After this test subjects, thinking that their alertness had been measured, had to complete the experimental task. In this task matrices, consisting of 9 different letters, appeared rapidly one after the other on the monitor. Whenever a predetermined letter appeared, subjects thad to react by pressing a key on the keyboard. After five trials subjects were told that they could stop but, if they continued they would receive more points. After these five trials, however, each correct response would yield fewer and fewer points (the first five trials were worth 10 points, after which the points decreased in a linear fashion until trial 14 which was worth 1 point, after which all subsequent trials would yield 1 point only). This procedure made it less attractive for subjects to continue. To ensure that the experiment did not take too long subjects had to stop after 40 trials. For each subject the number of correct and wrong responses were recorded, thus providing a measure for persistence (number of trials completed) and performance. 
Manipulation of causal attributions and feedback. After finishing the experimental task $k_{r}$ subjects received the attribution and feedback manipulation. The attribution manipulations differed from those in the first experiment. It was tried to augment the effect of these maniw pulations on the basis of deceptions prepared earlier in the experiment. Before subjects started to make the alertness test an ellectrode had been attached to their wrist. They were told that this electrode, which was attached to the computer, measured effort expenditure.

The pre-test that subjects made, supposedly, provided an estimate of their alertness, and subjects were told that the computer presented them (at random) with different levels of task difficulty. Because a lot of people had, allegedly, participated in this experiment, subjects were told that it was possible to compute correlations between effort expenditure (as measured by the electrode), alertness ability (measured by the alertness test) and task difficulty (determined and recorded by the computer) on the one hand and the performance of subjects on the other. After carefully explaining the concept of correlation, subjects in the effort condition would be presented with a high correlation between effort and performance (0.92) and low correlations between task difficulty and alertness on the one hand and performance on the other $(0.02$ and 0.04 respectively). In the ability condition the correlations with performance were 0.02 for effort, 0.04 for task difficulty and 0.92 in the case of ability. Likewise the task difficulty manipulation used correlations with performance of 0.02 for effort, 0.92 in the case of task difficulty and 0,04 for ability. The luck condition showed low correlations for all three variables $(0.02,0.04$, and 0.08 ), while subjects were informed that because nothing correlated highly with performance the only probable cause left was luck.

Directly after these manipulations the performance feedback manipulation followed. On a random basis half of the subjects received a very low score ( 30 out of a possible 100), the remaining half received a very high score ( 80 out of 100 ). This manipulation was followed by a short message appearing on the monitor stating in the effort/failure condition, that the electrode measurement had revealed that the low score was due to not having worked hard enough (effort/success: having worked hard enough). In the task difficullty/failure condition the message would stress that their failure was caused by the subject being presented with very difficult items (task difficulty/success: very easy items). Subjects in the ability/failure condition. would see that their failure was due to having a very low alertness ability (ability/failure: having a high alertness ability), something which was in accordance with their score on the pre-test. Finally, in the luck/failure and luck/success condition, it would again be stressed 
that since nothing correlated with performance their score was due to (bad) luck.

Dependent measures. After these manipulations subjects were asked to indicate what score they would achieve if they had to make the same task again. Thus having measured expectation of success the experimental task had to be made again. Different versions were used that were counterbalanced. Debriefing followed immediately after the experiment, after which subjects were paid.

\subsection{Results and discussion experiment 2}

Manipulation checks. A $2 \times 2 \times 2$ ANOVA with perception of performance as dependent variable revealed a significant main effect of the factor performance feedback. As intended subjects in the success conditions perceived their score as higher $(M=4.28)$ than subjects in the failure condition $(M=1.81, F(1,134)=526.42, p<.001)$. Beside this main effect, however, a first order interaction between stability and performance feedback $(F(1,134)=1028, p<.002)$ is found, which is qualified by a second order interaction between stability, internality and performance feedback $(F(1,134)=8.76, p<.004)$. This second order interaction is presented in Table 2.

After success the only significant difference found is between the external/stable (task difficulty) condition and the external/unstable (luck) condition. A high score on an easy task seems to be perceived as lower than a high score caused by luck. After failure attributing to task difficulty leads to the highest score compared with all other conditions.

Table 2. Perception of performance as a function of performance feedback, internality and stability of attributions.

\begin{tabular}{lllll} 
& \multicolumn{2}{c}{ Internal } & \multicolumn{2}{c}{ External } \\
\cline { 2 - 5 } & Stable & Unstable & Stable & Unstable \\
\hline Success & $4.08^{\mathrm{cd}}$ & $4.05^{\mathrm{cd}}$ & $3.80^{\mathrm{c}}$ & $4.38^{\mathrm{d}}$ \\
Failure & $1.58^{\mathrm{a}}$ & $1.50^{\mathrm{d}}$ & $2.25^{\mathrm{b}}$ & $1.57^{\mathrm{a}}$ \\
\hline
\end{tabular}

Note: Different letters indicate significant differences $(p<.05)$.

A $2 \times 2 \times 2$ ANOVA with perceived internality (Cronbach's $\alpha=.67)$, measured by the Causal Dimension Scale, as dependent variable revealed a significant effect of internality $(F(1,134)=10.49$, $p<.001)$. Subjects in the internal conditions perceived the cause of 
their performance as more internal $(M=6.12)$ compared to subjects in the external conditions $(M=5.27)$. A similar ANOVA with perceived stability (Cronbach's $\alpha=.65$ ) as dependent measure revealed a significant main effect of stability. Subjects in the stable conditions $(M=5.00)$ perceived their score as more stable than subjects in the unstable conditions $(M=4.41, F(1,134)=2.75, p<.05)$. Although the differences are, again, not large, the absence of interaction effects seems to indicate that our manipulations were more successful this time. The manipulations worked to the extent that even the, mostly very robust, self serving bias found in, for instance, the first experiment was not observed. Again it should be emphasized that the responses of the subjects revealed that some form of subjective internalization of the manipulated attribution did take place. Just like in the first experiment the manipulation consisted of presenting subjects with concrete causes of their failure (i.e. effort, ability, luck and task difficulty), which have been appropriately translated in terms of the underlying dimensions of causality (i.e. internality and stability).

Expectations of success. In order to properly investigate the effects of the manipulated attributional dimensions the effects of controllability should be partialled out first. A $2 \times 2 \times 2$ analysis of covariance with as dependent variable expectation of success and the combined controllability items (Cronbach's $\alpha=61$ ) as a covariate, revealed a significant interaction between the covariate and the performance manipulation $(F(1,126)=5.84, p<.02)$. There was no relation between controllability and expectation of success when subjects had succeeded $(F<1)$, whereas after failure, controllability was positively related to expectation of success $(\beta=.37, p<.004)$. Again it seems as if attributional variables are of less importance after success compared with failure. A $2 \times 2 \times 2$ analysis of covariance, in which different regression slopes are fitted for success and failure $(F(2,132)=7.51$, $p<.001$ ), reveals significant effects of the performance manipulation $(F(1,132)=24.78, p<.001)$, the manipulation of stability $(F(1,132)=9.70$, $p<.003)$, the interaction between stability and internality $(F(1,132)=$ $9.73, p<.003)$ and the interaction between the performance and stability manipulation $(F(1,132)=15.01, p<.001)$. Inspecting the adjusted means, it appears that subjects who experienced success had higher expectations of success $(M=6.94)$ than subjects who experienced failure $(M=4.44)$. Subjects who attributed their performance to stable causes $(M=5.61)$ had lower expectations of success than subjects attributing to unstable causes $(M=5.93)$. 
Table 3. Differences in expectations of success, adjusted for differences in controllability, as a function of internality and stability manipulations.

\begin{tabular}{lcc} 
& Stable & Unstable \\
\hline Internal & $5.77 \mathrm{a}$ & $5.59 \mathrm{a}$ \\
External & $5.39 \mathrm{a}$ & $6.33 \mathrm{~b}$ \\
\hline
\end{tabular}

Note: Different letters indicate significant differences $(p<.01)$.

The unpredicted interaction effect between internality and stability, irrespective of performance, is presented in Table 3. It seems as if attributions to luck, irrespective of performance, enhance expectations of success, while there are no differences in success expectations between the other attribution conditions. It seems as if people who think their success was due to luck expect to be lucky again, while people who think they failed because of bad luck expect to be lucky the next time.

Finally, there is an interaction effect of stability and performance. Table 4 contains the adjusted cell means representing this interaction effect. As in the previous experiment, it is found that stability of attributions influences expectations of success after failure. After success the difference is in the predicted direction but does not approach significance $(F<1)$.

Behavioral measures. All behavioral measures, number of items made and number of correct and wrong responses, were transformed into $z$ scores after which pre- to post-test change scores were computed. None of the variables revealed any differences across conditions on the pre-test (all $F_{s}<1$ ), nor were any significant interactions found. The change scores served as dependent measures in the analyses.

Preliminary analyses on changes in number of items completed as dependent variable revealed no order effects $(F(1,132)=1.43, p<.24)$, nor effects of controllability $(F(1,132)=2.17, p<.15)$. Subsequently, a simple $2 \times 2 \times 2$ analysis of variance with persistence as dependent variable revealed a significant effect of manipulated stability only $(F(1,133)=6.00, p<.02)$. Making unstable attributions for performance led to an increase in persistence $(M=.22)$ relative to making stable attributions $(M=-.14)$. Although the predicted interaction effect was not found, secondary analyses revealed, as predicted, a significant simple main effect of stability after failure $(F(1,125)=5.99, p<.03)$ but not after success $(F<1)$. 
Table 4: Differences in expectation of success, adjusted for differences in controllability, as a function of performance and stability manipulations.

\begin{tabular}{lll} 
& Stable & Unstable \\
\hline Success & $7.01^{\mathrm{c}}$ & $6.86^{\mathrm{c}}$ \\
Fauilure & $4.02^{\mathrm{a}}$ & $4.89^{\mathrm{t}}$ \\
\hline
\end{tabular}

Note: Different letters indicate significant differences $(p<.001)$.

An analysis of the dependent variable change in number of correct responses in a $2 \times 2 \times 2 \times 2$ analysis of covariance with controllability as a covariate showed a significant contribution of the covariate $(\beta=.17, F(1,123)=3.94, p<.05)$. After adjusting for these differences in controllability, main effects of performance $(F(1,123)=4.58, p<.04)$, stability $(F(1,123)=6.11, p<.02)$ and order $(F(1,123)=124.04, p<.001)$ were obtained. The last effect reflected nothing more than a difference in task difficulty between the two tasks. After success subjects give more correct responses $(M=.12)$ relative to subjects who experienced failure $(M=-.06)$. After making stable attributions subjects perform less well $(M=-.15)$ compared to making unstable attributions $(M=.24)$. In line with the results with regard to expectation of success and persistence significant simple main effects of stability are found after failure $(F(1,123)=4.22, p<.05)$ but not after success (both $F<1$ ).

Because no effect of controllability $(F<1)$ was found on the number of errors made, a simple $2 \times 2 \times 2$ analysis of variance with the number of errors as dependent variable was performed. This analysis revealed significant main effects of order $(F(1,125)=5.91, p<.02)$, again reflecting the difference in task difficulty, internality $(F(1,125)=$ $4.45, p<.04)$, and stability $(F(1,125)=3.67, p<.06)$. Attributing to stable causes led to making more errors $(M=17)$ relative to attributing to unstable causes $(M=-19)$. The main effect of internality, furthermore, showed that attributing to internal causes led to making more errors $(M=.15)$ than attributing to external causes $(M=-.17)$. Finally, an interaction between internality and performance $(F(1,125)=5.02$, $p<.03$ ) was found. This interaction is presented in Table 5.

Attributing success to internal causes resulted in making more errors compared to attributing success to external causes, while attributing failure to internal causes did not elicit more errors than attributing failure to external causes. 
Table 5. Differences in change in number of mistakes as a function of the performance and internality manipulations.

\begin{tabular}{lcc} 
& Internal & Extemal \\
\hline Success & $0.31 \mathrm{~b}$ & $-0.37 \mathrm{a}$ \\
Failure & $-0.01 \mathrm{a}$ & $0.02 \mathrm{a}$ \\
\hline
\end{tabular}

Note: Different letters indicate significant differences $(p<.001)$.

Testing the model. In order to test the attributional model presented earlier, several regression analyses have been performed. To predict, for instance, differences in the number of correct responses, persistence, expectations of success and manipulated attributions were entered into the regression equation. This order is based on the theoretical grounds presented in the introduction. Box's $M$ tests indicated that with regard to all variables separate analyses should be conducted for subjects in the success and failure conditions (all $p<, 001$ ). Results of the regression analyses are presented in Figures 1 and 2 .

Comparing these two figures shows clear differences between success and failure situations. After success, expectation of success is not influenced by any of the attributional variables. After failure, however, both stability and controllability influence expectation of success. In line with our hypothesis, it is found that the more stable the attributions people make for their failure, the lower their expectation of success. Expectations of success are, however, also influenced by perceptions of controllability: the more people attribute to controllable causes, the higher their expectation of success. After failure, no further direct or indirect of attributions are found. Differences in persistence explain a large part of the variance in performance as a result of which expectations and attributional variables do not improve the prediction. The only exception is the positive relationship between expectation of success and number of incorrect responses.

The results after success are more interesting. It can be seen that, after partialling out the effects of all the other variables, the more people attribute to controllable factors, the less correct responses they give. Furthermore, internality of attributions is positively related to the number of incorrect responses and to persistence. Stability, finally, is negatively related to persistence. It seems as if subjects who feel that they have proven themselves, that is subjects who attribute their successful performance to internal, stable and controllable 


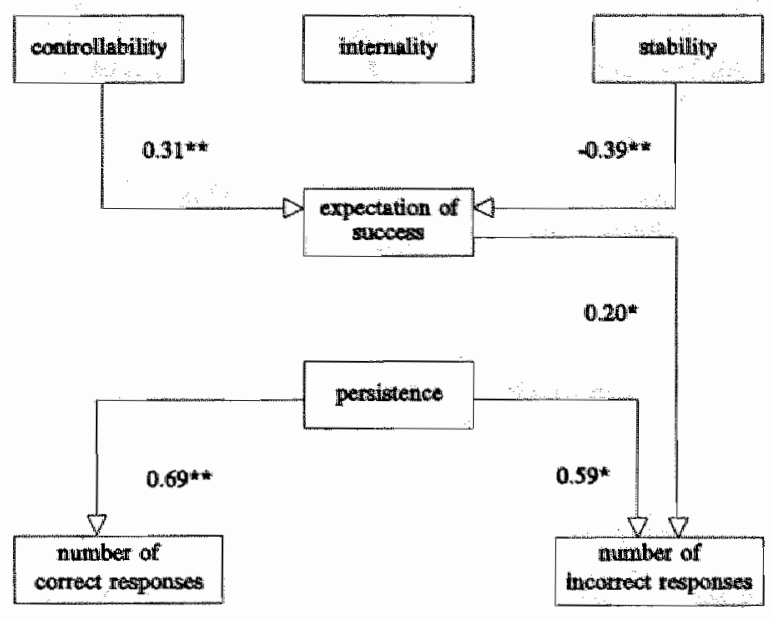

Figure 1. Regression anlysis after failure $\left({ }^{*} p<.001, " p<.05\right)$.

causes, are less motivated to succeed a second time. This might explain the absence of attributional effects after success found in the previous analyses.

\subsection{General discussion}

Looking back at the two experiments, several conclusions can be drawn with regard to our original question: how does reattribution work. Across the two experiments it has consistently been found that stable attributions lead to less adaptive cognitions and behavior than unstable attributions. Both experiments showed attributing to stable causes to lead to lower expectations of success after failure, and experiment 2 furthermore showed stable attributions to cause lower persistence, less correct responses and more incorrect responses relative to unstable attributions. Weiner's theory $(1985,1986)$ would predict these latter effects to be mediated by performance. The results described above fit in with the predictions of attribution theory relating to failure. With regard to expectation of success it was found after success that stable attributions lead to higher expectations of success compared to unstable attributions. This difference, however, 


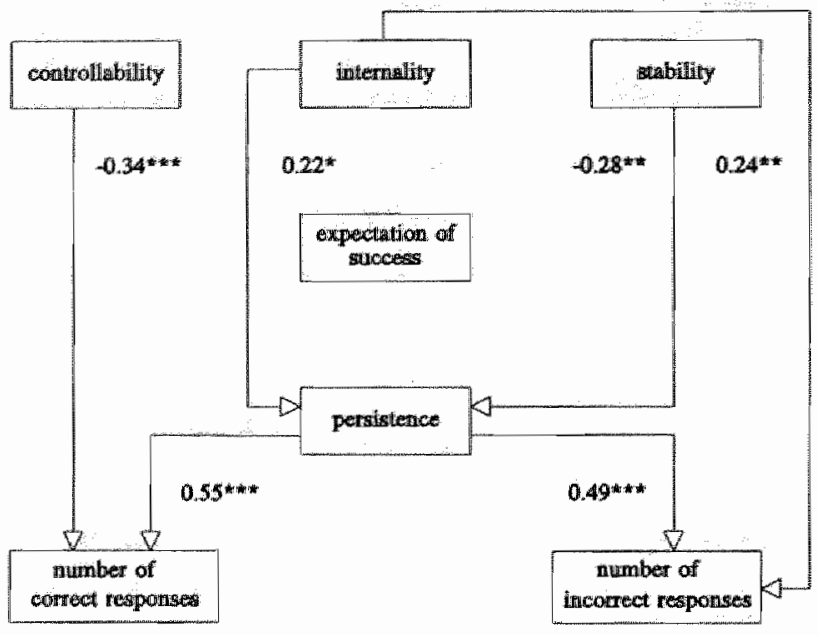

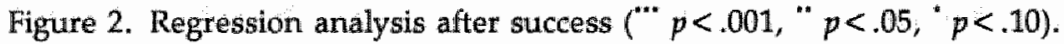

was never large enough to be significant. In the second experiment analyses performed after success and failure separately showed a simillar pattern for the behavioral measures. It might be concluded that we systematically found the predicted effect of stability after failure but not after success. The impact of attributional information seems to be much smaller after success compared to failure. This might be due to the reduced need to make attributions after success or to less motivation to succeed again after having experienced success.

Our hypothesis about the positive influence of controllability on expectation of success and behavioral variables received support too. In the second experiment we found positive effects of controllability estimates on expectations of success and on one of the behavioral variables, i.e. the number of correct responses given.

It may be concluded that the positive effects of the reattribution studies are probably largely due to the change in stability of attributions they achieve. Estimates of controllability seem to have a positive effect as well, but presumably not of the same magnitude.

Earlier in this article a point was made with regard to the persistence dependency of a task. The choice of the task in the second experiment was guided by the idea that performance on the task 
should be dependent on changes in persistence. Though intuitively the task used in the first experiment seems to be dependent on differences in effort investment as well. Whether or not finding behavioral effects in the second experiment is attributable to this choice of task can not be answered on the basis of these data. An experiment in which two kind of tasks, the one more persistence dependent than the other, are contrasted with each other is the only way to answer this question.

Summarizing we may conclude that this set of experiments has provided us with more information about mechanisms within attribum tion theory itself. The instability and controllability of effort attributions seem to be responsible for both an improvement at the cognitive and the behavioral level. With regard to attribution theory it can be said that these two experiments seem to indicate the need for more differentiation between success and failure situations. Furthermore it is found that stability is not the only attributional dimension which influences expectations of success, controllability seems to be important as well. Finally it can be noted that it might be more beneficial for subjects who succeeded to attribute their performance to unstable, uncontrollable and internal causes. This would ensure continued effort expenditure and motivation. 
$\vdots$ 


\title{
Chapter 4
}

\section{The effects of attributions and task difficulty on cognitions, emotions and performance ${ }^{1}$}

\author{
Abstract
}

Previous research has failed to demonstrate significant differences on behavioral variables like persistence and performance as a result of attributional manipulations. It has particularly not been proven that effort attributions made for one's own failure will result in a higher persistence and performance than other attributions. Two possible explanations are put forward. First it is assumed that tasks used previously were relatively complex, leaving no room for improvement by enhanced effort expenditure. The second possible explanation assumes that effort attributions evoke emotions that are detrimental to perfomance on complex tasks, thus counteracting the otherwise beneficial effect of the enhanced persistence. It is argued that an attribution to the combination of effort and task difficulty would not have such an effect. In order to examine these hypotheses a 2 (easy task vs. complex task) $x 3$ (attribution to effort, task difficulty or effort and task difficulty) experiment was performed. Results of this study largely support the original attributional hypotheses. Attributional effects are found for easy tasks but not for complex tasks. In general attributions to effort or the combination of effort and task difficulty lead to the highest expectation of success and persistence. Attributions to effort, however, lead to giving more correct and less incorrect answers than other attributions. This experiment, thus, provides support for the contention that effort is the "best" attribution to make after failure.

\subsection{Introduction}

Reattribution research (Försterling, 1985, 1988) departs from the assumption that it is possible to improve people's task performance by changing the attributions they make for previous failures (Weary, Stanley \& Harvey, 1989). On theoretical grounds an attribution to lack

"Submitted for publication as: Den Boer, D.J, Van Knippenberg, A.F.M., Meertens, R.M., \& Kok, G.J.. The effects of attributions and task difficulty on cognitions, emotions and performance. 
of effort is considered to be the most appropriate attribution after failure. In the present article two questions regarding this assumption will be addressed. Firstly attention will be paid to the question of how, or by what mechanisms, attributing own failure to effort enhances task performance. Secondly, it will be suggested that attributing own failure to lack of effort may not, in all cases, elicit higher levels of performance on subsequent, similar tasks. It will be argued that, in general, the effectiveness of a particular attribution in terms of subsequent task behavior depends on what kind of task is involved, and on the nature and level of emotions aroused.

With regard to the first question it can be hypothesized that effort attributions for failure enhance performance by influencing expectations of success and emotions. Following Weiner's attribution theory (1985, 1986) subjective expectations of success will be enhanced because of the instability implied in effort attributions, while the concomitant internality and controllability are assumed to evoke motivating emotions. Both expectations of success and motivating emotions are assumed to be positively related to persistence and performance.

Evidence for this line of reasoning may be found in reattribution studies. Such studies typically compare an experimental group of individuals who receive a so-called 'reattribution training' with a control group not subjected to such a training (see Försterling, 1988, for a review). In general these studies show positive effects of reattribution training in comparison to control groups. While these studies show that attributing failure to effort leads to an enhanced performance, it still remains unclear whether the effects of attributing to effort are caused along the lines discussed above.

Evidence for these causal relations could only be found in studies which manipulated different attributions and measure the resulting expectations of success, emotions, persistence and performance. Studies like these, however, seem to be rare. A search of the literature revealed only two studies which measured some of these effect variables and manipulated attributions made for own actual success (Kernis, Zuckerman \& McVay, 1988; Riemer, 1975), and only one which manipulated attributions made for own actual success and failure (Den Boer, Meertens, Kok \& Van Knippenberg, submitted). In this last study two experiments are reported in which task performance and attributions made for that performance were manipulated. The results of both these experiments supported the predictions derived from Weiner's attribution theory only in the cognitive domain (i.e. effects of stability of attributions on expectation of success). The hypothesized relations between cognitive and behavioral variables, however, were not found. So far, therefore, there seems to be no 
truly experimental evidence for the hypothesis that effort attributions made for own failure will enhance task performance more than other attributions.

The absence of behavioral effects in our previous study might be attributed to the choice of tasks. The views put forward by Kahneman (1973; see also Manstead \& Semin, 1980) with regard to task performance and energy allocation may be relevant here. Kahneman suggests that in the execution of easy tasks, subjects do not activate all available energy resources, but tend to perform on a sub-optimal level, retaining some amount of spare capacity which in principle could be used to improve performance. On complex tasks, however, subjects are inclined to mobilize all their energy in performing the task. In other words, easy tasks tend to elicit relaxed task performance, while complex tasks incite maximum effort expenditure from the start. The implication of this argument would be, then, that motivating interventions (e.g. attributional interventions) might be capable of enhancing performance on easy tasks, whereas such interventions would not be effective in improving performance on complex tasks.

In the latter case, attributing failure to effort might even deteriorate task performance. Considering the results of two studies done by Weiner, Russell and Lerman $(1978,1979)$ it seems as if emotions associated with attributing failure to internal causes are more intense than those related to attributing failure to external causes. Research on social facilitation and inhibition (cf. Paulus, 1983; Wilke \& Van Knippenberg, 1988; Zajonc, 1965) demonstrates that, given complex tasks, enhanced arousal may lead to deterioration of task performance. In other words social facilitation theory predicts that to the extent that emotions, elicited by the attributional explanation for failure, bring about arousal, subsequent performance on complex or difficult tasks may be inhibited. On easy tasks, however, emotions and the accompanying arousal, associated with attributing failure to effort, would lead to the amelioration of task performance.

A more attributional minded explanation of the absence of behavioral effects in our previous study would assume that attributing failure to effort might have, in the case of complex or difficult tasks, two partly conflicting effects. On the one hand it is assumed to be beneficial because it may enhance expectations of success and, thus, persistence. On the other hand, though, it might evoke levels of emotions that result in 'irrelevant processing" (cf. Paulus, 1983). These two effects might counteract each other and, as a consequence, attributing failure to effort would only be more effective than other attributions in terms of variables like expectations of success. On behavioral variables (e.g. task performance), however, this beneficial effect would be balanced by the negative effect of enhanced arousal 
accompanying the intense emotions associated with attributions to effort. In summary, then, the absence of effects on the performance level, found in our previous study (Den Boer ef al., submitted) might be explained by the intensity of emotions which counteracts the, otherwise, beneficial effects of attributing failure to effort. Performance effects of effort might have been obtained, however, if less complex or more easy tasks had been used.

Extending this argument implies that, with regard to improving task performance on complex tasks, attributing failure to other causes than lack of effort might be worth considering (see also Clifford, $1986^{a}$, 1986' Wilson \& Linville, 1982, 1985). A study reported by Den Boer, Meertens; Kok and Van Knippenberg (1989) suggests that the combination of effort and task difficulty might reduce the adverse emotional effects. Secondary analyses of the data obtained in this study revealed that the combined attribution of task difficulty and effort was more strongly associated with enhanced performance than an attribution to effort alone. The task difficulty component of the attribution might serve to ward off the effects of strong emotions, while the message conveyed by the inclusion of the effort attribution might elicit enhanced investment of effort in a similar future task.

Both the social facilitation and the attributional explanation, put forward above, predict with regard to easy tasks that effort attributions will lead to higher expectation of success, higher persistence and improved performance compared with attributions to the combination of effort and task difficulty or to task difficulty alone. An attribution to the combination of effort and task difficulty, in turn, is predicted to lead to higher expectations of success, persistence and performance than an attribution to task difficulty alone.

For complex tasks two different hypotheses can be formulated. Again the predictions of both explanations are similar for expectations of success and persistence but different for performance. Similar to the case of easy tasks, both explanations predict that an effort attribution leads to higher expectation of success and persistence than the combined attribution to task difficulty and effort which, in turn, leads to higher expectations of success and persistence than an attribution to task difficulty alone. With regard to performance variables there is a difference between the two theoretical points of view. The attributional explanation predicts an attribution to the combination of effort and task difficulty to lead to a higher performance than either an attribution to effort or task difficulty alone. The social facilitation explanation, however, predicts that an attribution to task difficulty alone, would elicit the least irrelevant processing. This attribution leads to the highest performance compared to either an attribution to effort or an attribution to the combination of effort and task difficulty 


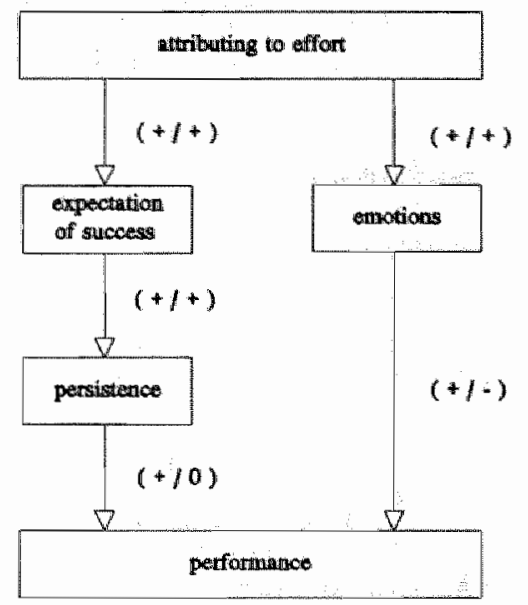

Figure 1. Predicted attributional influences on cognitions, emotions and behavior for easy tasks (first sign) and complex tasks (second sign).

after failure on complex tasks. An attribution of failure to the combination of effort and task difficulty, finally, will lead to a better performance on complex tasks than an attribution to effort alone.

Note that in the predictions above, it is implicitly assumed that persistence covaries with expectations of success, but not necessarily with performance. Subjects may as a consequence of their attribution of previous failure, be optimistic about future success and will, therefore, be motivated to work harder, that is show more persistence in carrying out the task. Such persistence may enhance task performance on easy tasks, but may be ineffective with regard to performance on complex tasks.

Having formulated our hypotheses, it is possible to formalize these relations in a model. This model (see Figure 1), proposes that effects of attributions on performance are mediated by expectations of success, emotions and persistence. The effects of attributions on persistence are also indirect, i.e. mediated by differences in expectations of success. It is furthermore hypothesized that after easy tasks there will be an effect of attributions, via expectations of success and persistence, on performance. The latter effect on performance, however, is not predicted for complex tasks. 


\subsection{Method}

Subjects. Seventy-six (76) undergraduate students of the University of Limburg (The Netherlands) participated in this experiment. Subjects were volunteers who responded to an advertisement in the university newspaper. For their participation each subject received 20 Dutch guilders (approximately $\$ 10.00$ ). The mean age of subjects was 20.2 years.

Design and procedure. The design of this study was a 2 (easy task vs. difficult task) $\times 3$ (attribution to effort, attribution to task difficulty or attribution to the combination of effort and task difficulty) factorial design. The main dependent variables were expectation of success, emotions, persistence and performance.

Subjects arrived in groups of at most six persons. All information was provided by means of a personal computer and subjects typed in their answers on the keyboard. The alleged purpose of the experiment was to investigate the relation between the ability "alertness" and performance on a specific task. Alertness was explained as having to do with quick and adequate responding to unexpected situations.

In order to set the stage for a convincing induction of the attributional manipulations used later in the experiment, a bogus test, measuring the focal ability (alertness) and bogus equipment for measuring effort expenditure was applied. Subjects had an electrode attached to their wrist which was connected with the computer. They were told that this electrode would record their effort expenditure.

After finishing the bogus alertness test subjects had to complete either an easy or a complex task. On a random basis half of the subjects received the difficult task. Square matrices, containing 9 different letters, appeared on the monitor. After a short time varying from 3 to 7 seconds the matrix disappeared from the screen and subjects were asked to recall which 3 letters were in the first, second or third row (see Long (1980) for factors influencing performance on this kind of task). After five such matrices subjects could either quit the task or continue. They were told, however, that they would receive a progressively decreasing amount of points for each correctly answered question (the first five questions, if answered correctly, were awarded 10 points, after which the allocated amount of points decreased in a linear fashion until eventually further questions, if answered correctly, would only yield 1 point). This procedure was followed to make it increasingly less attractive over time to persist. To prevent excessive prolongation of experimental sessions the task was terminated after 40 trials. 
Subjects in the easy task condition received the same task, but were simply allowed more time to inspect the matrices. Whereas in the other task version subjects only had a short time (3-7 seconds), subjects in the this condition were allowed to look at each matrix for 18 to 22 seconds. Thus, in the latter task conditions, increased effort investment could improve task performance, because subjects would have the opportunity to memorize the matrix content.

Manipulation of causal attributions. After finishing the experimental task subjects received bogus feedback about their task performance and the attribution manipulation. The test the subjects had made previously provided, allegedly, a fairly accurate estimate of their alertness. Furthermore the subjects were told that the computer randomly selected a different level of task difficulty for each subject. As the subjects were led to believe that a great number of subjects had participated in this experiment, they could be told that correlations between effort expenditure (as registered by the electrode attached to their wrist), alertness ability (measured by the alertness test) and task difficulty (selected and recorded by the computer) on the one hand and the performance of subjects on the other could be computed. After carefully explaining the concept of correlation, subjects in the effort condition would be presented with a high correlation between effort and performance (0.92) and low correlations between task difficulty and alertness on the one hand and performance on the other $(0.02$ and 0.04 respectively). The task difficulty manipulation comprised of correlations of 0.02 , and 0.04 between effort and ability on the one hand and performance on the other. This condition showed a correlation of 0.92 between task difficulty and performance. The combined task difficulty/effort condition, finally, consisted of correlations of 0.71 between task difficulty and performance, 0.73 between effort and performance and 0.02 between ability and performance.

Performance feedback was given immediately after these manipulations. All subjects received a very low score (30 out of a maximum of 100 points) and were also told explicitly that this was a very low score. After this bogus feedback a message appeared on the monitor containing additional attributional information. In the effort condition subjects learned that according to the measure obtained from the electrode the subject had not worked hard enough. In the task difficulty condition the message would state that the subject had been presented with very difficult items. And finally in the combined effort/task difficulty condition subjects were told that the items they had to answer were very difficult but that they had not worked hard enough to cope with these difficulties. This additional information served to reinforce the previously presented somewhat abstract 
correlational information by explicating its specific implications in simple terms.

Mantpulation checks. Manipulation checks followed after presenting the bogus feedback and the attribution manipulation. First subjects had to fill in a Dutch version of the Causal Dimension Scale (CDS, Russell, 1982), which measures internality, stability and controllability of the cause one holds responsible for a specific outcome. In order to evoke subjective processing of attributional information the subjects were asked to consider which cause they themselves held responsible for their failure. Subsequently they were asked to complete the CDS bearing this cause in mind.

Dependent measures. Expectation of success was measured by asking subjects how well they expected to perform, if they had to do a similar task of the same difficulty, in a different version, again. Finally they had to answer several questions about the extent to which they experienced certain emotions (5-point scale; $1=$ not at all, $5=$ very much). In order to be able to make comparisons with earlier studies the list of items used by Russell and McAuley (1986) was adapted. The resulting item list contained the (Dutch equivalent of the) following emotions: satisfied, content, happy, relaxed, optimistic, disappointed, displeased, resigned, downhearted, upset, sad, depressed, competent, confident, smart, inadequate, incompetent, stupid and ashamed.

Subsequently subjects carried out a second task, which was a different version of the task performed earlier. Earlier in the experiment it had been made clear that they would have to make a similar task again and that there would be no variation in difficulty level across tasks. The two versions of the task were counterbalanced. After completion of this second task subjects were debriefed and received their payment.

\subsection{Results}

Manipulation checks. Preliminary analyses of the subscales of the CDS revealed that the internality scale and the stability scale had low Cronbach's $\alpha$ 's $(<.50)$. Deletion of two items ("an aspect of the situation vs. an aspect of yourself" and "unchangeable vs. changeable" ) led to a substantial increase in the reliability of these measures (internality: $\alpha=.88$; stability: $\alpha=.68$ ).

Analysis of variance in a $2 \times 3$ design with internality as dependent measure revealed significant effects of the attribution factor only. As intended, subjects in the effort condition attributed their failure more internally $(M=.20)$ compared to subjects in the task difficulty 
condition $\left(M=-.30, F(1,70)=3.05, p_{\text {anesided }}<.04\right)$. Subjects in the effort and task difficulty condition indicated an intermediate level of internality of attributions $(M=12)$ which did not differ significantly from the two other conditions. No effects of task or interaction effects were found.

Analysis of the stability measure revealed that subjects in the effort condition attributed less stable $(M=-.41)$ compared with subjects in the task difficulty condition $(M=.20, F(1,70)=6.02, p<.02)$ or subjects in the task difficulty and effort condition $(M=.27$, $F(1,70)=5.06, p<.03)$. No other differences were significant.

Considering these manipulation checks, it should be emphasized that the responses of the subjects suggest that some form of subjective internalization of the manipulated attribution must have taken place. While the manipulation consisted of presenting subjects with concrete causes of their failure (i.e. effort, task difficulty, both effort and task difficulty), they appear to have appropriately translated these attributions in terms of the underlying dimensions of causality (i.e. internality and stability).

In order to check the manipulation of the nature of the task, subjects were asked to indicate, on a 5-point scale, how difficult they found the task they had just made. Subjects in the easy task condition rated the task as less difficult $(M=2.49)$ than subjects in the difficult task condition $(M=2.92, F(1,70)=4.51, p<.04)$.

Expectations of success, persistence and performance. Expectations of success, number of items completed on the first and second task, number of correct responses and number of incorrect responses on the first and second task were converted to $z$-scores. The $z$-score representing the number of incorrect responses was subtracted from the $z$ score representing the number of correct responses, which thus provides an estimate of how subjects had performed. After these transformations pre- to post-test change scores were computed. None of the pre-test scores differed across experimental conditions (all $F<1$ ).

A $2 \times 3$ multivariate analysis of variance revealed a multivariate significant effect of the attribution manipulation $(F(6,136)=3.41$, $p<.005)$ and of the interaction between the attribution and task manipulation $(F(6,136)=1.95, p<.08)$. The multivariate main effect of the attribution manipulation may be attributed to univariate significant effects on expectation of success $(F(2,69)=3.55, p<.04)$ and performance $(F(2,69)=5.66, p<.006)$. It was hypothesized that attributing to effort would, irrespective of the task, lead to a higher expectation of success than attributing to the combination of effort and task difficulty. The latter attribution would lead to a higher expectation of success than attributing to task difficulty alone. As expected it was 
found that subjects who attributed their failure to effort $(M=.26)$ or the combination of effort and task difficulty $(M=.18)$ raised their expectations of success compared to subjects attributing their failure to task difficulty alone $(M=-.41, F(1,69)=6.20, p<.02 ; F(1,69)=4.38$, $p<.04$, respectively). Contrary to the hypothesis, however, the difference between the effort and the combination condition was nonsignificant.

With regard to performance the two theories predicted different effects. Both the social facilitation and the attributional hypothesis predicted that; given easy tasks, an attribution to effort would lead to a better performance than an attribution to the combination of effort and task difficulty, which would be better than an attribution to task difficulty alone. After difficult tasks the attributional hypothesis predicts the combined attribution to effort and task difficulty to be better than either of the two other attributions. The social facilitation hypotheses, however, predicts an attribution to task difficulty to elicit a better performance than an attribution to effort or to the combination of effort and task difficulty. Inspecting the data it may be observed that, contrary to both hypotheses, subjects attributing failure to effort $(M=.68)$, irrespective of task, relatively increased their performance while subjects in the task difficulty condition $(M=-.43)$ and the combination condition $(M=-.23, F(1,69)=9.73, p<.004 ; F(1,69)=6.92$, $p<.02$, respectively) relatively decreased their performance. Considering the latter result, it may be of interest to look at the number of correct and incorrect answers separately. Analysis of the change in correct responses yields a main effect of the attribution manipulation $(F(2,69)=2.81, p<.07)$ and an interaction effect $(F(2,69)=2.72, p<.08)$. Subjects in the effort condition relatively increase the number of correct responses $(M=.31)$ while subjects in the task difficulty condition $(M=-.23, F(1,70)=5.57, p<.03)$ show a relative decrease. The mean in the combination condition $(M=.07)$ differs from neither of the other two conditions.

The interaction effect is presented in Table 1. Contrary to both hypotheses, no differences are found after a difficult task. After an easy task, however, differences parallel to those observed in the main effect are found. As predicted by both hypotheses attributing to effort leads to more correct responses than attributing to task difficulty alone. Again, as predicted, attributing to the combination of task difficulty and effort leads to an intermediate position.

Analysis of the number of incorrect responses reveals a main effect of the attribution manipulation only $(F(2,69)=4.01, p<.03)$. After an effort attribution subjects appear to give less incorrect answers $(M=-.35)$ compared to subjects attributing to task difficulty 
Table 1. Change in number of correct responses as a function of task and attribution manipulation.

\begin{tabular}{lccc}
\cline { 2 - 4 } & Effort & Task difficulty & Combination \\
\hline Easy task & $0.68^{\mathrm{c}}$ & $-0.44^{\mathrm{b}}$ & $0.12^{\mathrm{bc}}$ \\
Complex task & $-0.01^{\mathrm{a}}$ & $-0.02^{\mathrm{ab}}$ & $0.03^{\mathrm{ab}}$ \\
\hline
\end{tabular}

Note: Different letters indicate significant differences $(p<.05)$.

$(M=.21, F(1,70)=7.02, p<.01)$ or the combination of task difficulty and effort $(M=.32, F(1,70)=4.62, p<.04)$.

With regard to persistence it was hypothesized that attributing to effort would, irrespective of the task, lead to a higher persistence than attributing to the combination of effort and task difficulty. This latter attribution would lead to a higher persistence than attributing to task difficulty alone. The multivariate interaction effect, presented earlier, can be attributed to the univariate interaction effect on persistence $(F(2,69)=2.87, p<.07)$ only. Table 2 shows that, contrary to the hypotheses, after a difficult task no differences between attribution conditions arise, while after an easy task attributions to effort or the combination of effort and task difficulty lead to higher persistence compared to attributions to task difficulty alone.

This pattern of results, absence of differences after a difficult task and presence of differences after an easy task, was also obtained for expectation of success and performance. The simple effect of the attribution manipulation on easy task is significant for both expectation of success and performance (respectively $F(2,69)=4.76, p<.02$, $F(2,69)=6.09, p<.005)$. For the difficult task, however, both effects are not significant $(F s<1)$. These differences in effect, however did not lead to univariate interaction effects.

Table 2. Change in persistence as a function of task and attribution manipulation.

\begin{tabular}{llcc} 
& Effort & Task difficulty & Combination \\
\hline Easy task & $0.57^{\mathrm{b}}$ & $-0.65^{\mathrm{a}}$ & $0.13^{\mathrm{b}}$ \\
Complex task & $0.00^{\mathrm{ab}}$ & $-0.16^{\mathrm{ab}}$ & $0.24^{\mathrm{ab}}$ \\
\hline
\end{tabular}

Note: Different letters indicate significant differences $(p<, 05)$. 
Table 3. Factor solution, after varimax rotation, for the emotion items (55.8\% of variance explained).

\begin{tabular}{|c|c|c|c|}
\hline emotion & factor 1 & factor 2 & factor 3 \\
\hline satisfied & -0.13 & 0.76 & 0.16 \\
\hline content & -0.10 & 0.74 & -0.06 \\
\hline happy & -0.03 & 0.56 & 0.40 \\
\hline relaxed & -0.49 & 0.36 & 0.14 \\
\hline optimistic & -0.27 & 0.37 & 0.41 \\
\hline disappointed & 0.39 & -0.63 & 0.01 \\
\hline displeased & 0.46 & -0.55 & -0.05 \\
\hline resigned & 0.84 & -0.12 & 0.01 \\
\hline downthearted & 0.77 & -0.24 & -0.08 \\
\hline upset & 0.70 & -0.20 & 0.03 \\
\hline sad & 0.83 & -0.21 & -0.07 \\
\hline depressed & 0.76 & -0.05 & -0.08 \\
\hline disturbed & 0.75 & -0.22 & -0.22 \\
\hline proud & 0.16 & 0.09 & 0.54 \\
\hline competent & -0.07 & 0.13 & 0.56 \\
\hline confident & -0.08 & -0.13 & 0.85 \\
\hline smart & -0.13 & 0.08 & 0.79 \\
\hline inadequate & 0.75 & -0.06 & 0.06 \\
\hline incomptent & 0.74 & -0.03 & 0.14 \\
\hline stupid & 0.79 & -0.14 & -0.15 \\
\hline shame & 0.64 & -0.29 & -0.12 \\
\hline
\end{tabular}

Enotions. Factor analysis on all the emotion items yields a 3 factor structure which is interpretable and where all factors have an eigenvalue larger than 1 . These 3 factors account for 55.8 percent of the variance. After varimax rotation the following interpretation of these factors may be made (see Table 3 ).

Factor 1 can be interpreted as general negative emotions, while factor 2 denotes general positive emotions. The third factor, finally, can be referred to as a factor related to competence. 
Separate analyses of variance reveal effects for the positivity factor only. The attribution manipulation has $\mathrm{a}_{\text {, marginally, significant effect }}$ $(F(2,69)=2.57, p<.09)$. Subjects in the task difficulty condition experience more positive affect $(M=.37)$ compared to either the subjects in the effort condition $(M=-.20, F(1,70)=3.63, p<.06)$ or the combination condition $(M=-.24, F(1,70)=4.16, p<.05)$. The difference between the effort condition and the combination condition was not significant.

Testing the model. In order to test the attributional model presented in Figure 1, several hierarchical regression analyses have been performed. The order in which predictors are entered in the regression equation is based on theoretical grounds. From Figure 1 two rules can be deduced. Firstly manipulated attribution is always entered last in the equation and, secondly, expectations of success always follows after persistence. To predict, for instance, performance three possible orders to enter the variables can be considered: (1) Persistence followed by emotions and expectations of success, (2) Persistence followed by expectation of success and emotions, and, finally, (3) Emotions followed by persistence and expectation of success. All of these are followed by manipulated attribution.

Box's $M$ tests indicate that with regard to all variables separate analyses should be conducted for the two task groups (all $p<.01$ ). The focus of this study being how effects of attributions on performance can be explained and considering that only the positive emotion factor was influenced by differences in attributions, the other emotion factors will be ignored. Results of these regressionanalyses are presented in Table 4 and $5^{2}$.

As can be deduced from these tables performance in the easy task condition is more sensitive to differences in persistence than performance in the difficult task condition. This is largely due to the fact that in the difficult task condition making more items leads to giving more correct responses as well as incorrect responses, whereas in the easy task condition making more items leads to giving more correct responses only.

With regard to the attributional model presented in Figure 1 it can be stated that the results of these analyses fit the model, in the case of easy tasks, remarkably well. Figure 2 summarizes these results by reporting for each analy'sis the first set of steps. Despite the small number of subjects in each task condition significant relations or trends are found which fit the model. As predicted it is found that

${ }^{2}$ In these analyses manipulated attribution is codes as follows: $1=$ attribution to taskdifficulty alone, 2 = attribution to both taskdifficulty and effort, and 3 = attribution to effort alone. 


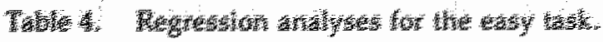

\begin{tabular}{|c|c|c|c|c|c|c|c|}
\hline 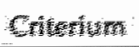 & 5 & Patson & 露 & 政 & 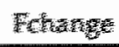 & 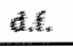 & $1<$ \\
\hline \multirow{2}{*}{$\begin{array}{l}\text { Patom } \\
\text { dathe }\end{array}$} & 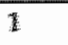 & Ther & 32 & $\sqrt{2}$ & 398 & 1,34 & 16 \\
\hline & 2 & Pow & .26 & 4 & 36 & , 3 & (4) \\
\hline \multirow{4}{*}{ ¿ } & 3 & Y) & 14 & 4 & 21 & 1,32 & $n$ \\
\hline & & : & & & & & \\
\hline & 䇺 & 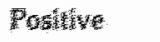 & .28 & 23 & 箪丵7 & 1,34 & res \\
\hline & 2 & 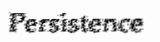 & 3 & 43 & 53 & 33 & .6 \\
\hline \multirow[t]{5}{*}{ 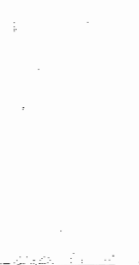 } & 3 & 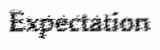 & .34 & 45 & 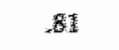 & 1,32 & ws \\
\hline & 1 & Matsinger & 32 & 32 & 3.93 & 1,3 & 96 \\
\hline & 2 & 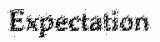 & .8 & .34 & 4 & 133 & TSE \\
\hline & 3 & Protiche & 30 & 45 & 3.57 & 1,32 & $m$ \\
\hline & 4 & Antroturuton & 43 & 程 & 5.89 & 1,3 & .02 \\
\hline \multirow{5}{*}{ 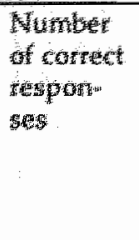 } & 1 & Prsistence & .8 & .80 & 61.38 & 1,34 & .601 \\
\hline & 2 & Postrue & .17 & .82 & 2.80 & 1,33 & .11 \\
\hline & 3 & Reperdaton & 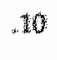 & .83 & 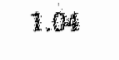 & $n_{n}, z_{2}$ & $n$ \\
\hline & 1 & chorive & 0 & 9 & 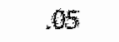 & 134 & $n s$ \\
\hline & 2 & Persistance & .9 & 82 & 67.30 & 1,35 & $.00 x$ \\
\hline & 3 & Expectator & +10 & .83 & 1,0 & 1,32 & 蛙: \\
\hline & 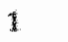 & Persistence & .90 & .80 & 61.38 & 1,34 & .00 \\
\hline & 2 & Fupectionon & .08 & 81 & .63 & 3 & ns \\
\hline & 3 & Positave & .38 & .83 & 3.17 & 1,32 & .09 \\
\hline
\end{tabular}

\begin{tabular}{|c|c|c|c|c|c|c|c|}
\hline $\begin{array}{l}\text { Wurbuer } \\
\text { of incor- } \\
\text { rect res- } \\
\text { ponses }\end{array}$ & 4 & Atribution & .27 & .86 & 5.98 & 1,3 & .02 \\
\hline \multirow{9}{*}{$\begin{array}{l}\text { Number } \\
\text { of incor } \\
\text { rect rest } \\
\text { ponses }\end{array}$} & 1 & Persistence & 25 & .25 & 2.28 & 1,34 & .14 \\
\hline & 2 & Positive & -0.30 & .39 & 3.44 & 1,33 & .06 \\
\hline & 3 & Expectation & -0.13 & .41 & .66 & 1,32 & ns \\
\hline & 1 & Posilive & -0.33 & .33 & 4.27 & 1,34 & .05 \\
\hline & 2 & Persistence & .20 & .39 & 1.55 & 1,33 & ins. \\
\hline & 3 & Expectation & -0.13 & .41 & .66 & 1,32 & ns \\
\hline & 1 & Persistence & .25 & .25 & 2.28 & 1,34 & .14 \\
\hline & 2 & Expectation & -0.09 & .27 & .33 & 1,33 & ns \\
\hline & 3 & Positive & -0.32 & .41 & 3.71 & 1,32 & .07 \\
\hline
\end{tabular}

\begin{tabular}{lllrrrrr} 
& 4 & Attribution & -0.43 & 54 & 5.63 & 1,31 & .03 \\
\hline Persis- & 1 & Expectation & -0.02 & .02 & .02 & 1,34 & $\mathrm{~ns}$ \\
tence & 2 & Attribution & .39 & .36 & 4.86 & 1,33 & .04 \\
\hline $\begin{array}{l}\text { Expecta- } \\
\text { tion }\end{array}$ & 1 & Attribution & .44 & .44 & 8.31 & 1,34 & .007 \\
\hline Positive & 1 & Attribution & -0.29 & .29 & 3.00 & 1,34 & .10 \\
\hline
\end{tabular}


Table 5. Regression anallyses for the complex task.

\begin{tabular}{|c|c|c|c|c|c|c|c|}
\hline Criterium & Step & Predictor & $B$ & $\mathbf{R}$ & Fchange & d.f. & $p<$ \\
\hline \multirow{10}{*}{$\begin{array}{l}\text { Perform- } \\
\text { ance }\end{array}$} & 1 & Persistence & -0.01 & .01 & .00 & 1,37 & $\mathrm{~ns}$ \\
\hline & 2 & Positive & -0.15 & .15 & 77 & 1,36 & ns \\
\hline & 3 & Expectation & .21 & .25 & 1.46 & 1.35 & ns \\
\hline & 1 & Positive: & -0.14 & .14 & .79 & 1,37 & $n s$ \\
\hline & 2 & Persistence & -0.02 & .15 & .01 & 1,36 & ns \\
\hline & 3 & Expectation & .21 & $.25 i$ & 1.46 & 1,35 & ns \\
\hline & 1 & Persistence & -0.01 & .01 & .00 & 1,37 & ns \\
\hline & 2 & Expectation & .23 & .22 & 1.85 & 1,36 & ns \\
\hline & 3 & Positive & -0.11 & .25 & .43 & 1,35 & ns \\
\hline & 4 & Attribution & .28 & .37 & 2.85 & 1,34 & .11 \\
\hline \multirow{10}{*}{$\begin{array}{l}\text { Number } \\
\text { of correct } \\
\text { respon- } \\
\text { ses }\end{array}$} & 1 & Persistence & .88 & .88 & 124.28 & 1,37 & .001 \\
\hline & 2 & Positive & -0.07 & .88 & .80 & 1,36 & nS \\
\hline & 3 & Expectation & .10 & .89 & 1.52 & 1,35 & $n s$ \\
\hline & 1 & Positive & -0.12 & .12 & .47 & 1,37 & $\mathrm{~ns}$ \\
\hline & 2 & Persistence & .88 & .88 & 122.40 & 1,36 & .001 \\
\hline & 3 & Expectation & .10 & .89 & 1.54 & 1,35 & nst \\
\hline & 1 & Persistence & .88 & .88 & 124.28 & 1,37 & .001 \\
\hline & 2 & Expectation & .11 & .88 & 1.91 & 1,36 & ns \\
\hline & 3 & Positive & -0.05 & .89 & .44 & 1,35 & ns \\
\hline & 4 & Attribution & .13 & .90 & 2.83 & 1,34 & .21 \\
\hline \multirow{10}{*}{$\begin{array}{l}\text { Number } \\
\text { of incor- } \\
\text { rect res- } \\
\text { ponses. }\end{array}$} & 1 & Persistence & .78 & .78 & 55.85 & 1,37 & .001 \\
\hline & 2 & Positive & .09 & .78 & .76 & 1,36 & ns \\
\hline & 3 & Expectation & -0.13 & .79 & 1.43 & 1,35 & $\mathrm{~ns}$ \\
\hline & 1 & Positive & .05 & .05 & .11 & 1,37 & nis \\
\hline & 2 & Persistence & .78 & .78 & 55.99 & 1,36 & .001 \\
\hline & 3 & Expectation & -0.13 & .79 & 1.43 & 1,35 & ns \\
\hline & 1 & Persistence & .78 & .78 & 55.85 & 1,37 & .001 \\
\hline & 2 & Expectation & -0.14 & .79 & 1.81 & 1,36 & nis \\
\hline & 3 & Positive & .07 & .79 & .42 & 1,35 & ns \\
\hline & 4 & Attribution & -0.43 & .54 & 5.63 & 1,34 & .03 \\
\hline \multirow{2}{*}{$\begin{array}{l}\text { Persis- } \\
\text { tence }\end{array}$} & 1 & Expectation & .26 & .26 & 2.67 & 1,37 & .11 \\
\hline & 2 & Attribution & -0.18 & .32 & 1.26 & 1,36 & ns \\
\hline $\begin{array}{l}\text { Expecta } \\
\text { tion }\end{array}$ & 1 & Attribution & .08 & .08 & .22 & 1,37 & $\mathrm{~ns}$ \\
\hline Positive & 1 & Attributon & .0 .09 & 09 & .30 & 1,37 & $\mathrm{n} . \mathrm{s}$ \\
\hline
\end{tabular}




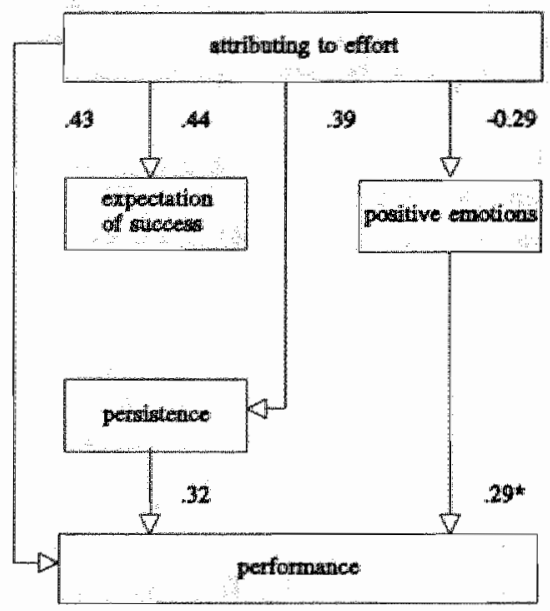

Figure 2. Attributional influences on cognitions, emotions and behavior after making easy tasks ( this relation is only present if persistence is entered into the equation before positive emotions).

the manipulated attributions influence both emotions and expectation of success. Positive emotions in turn are related to performance, although this effect is only present when persistence is already in the equation. It seems as if the positive emotions factor plays the role of suppressor variable (Tabachnick \& Fidell, 1989, p. 161). This is confirmed by the fact that both persistence and positive emotions have a positive zero order correlation with performance $(r=.32, p<.06$, and $r=.23, p<.11$, respectively) but have a negative zero order correlation $(r--16, p<.18)$ with each other. This negative correlation, of course, is due to the fact that attributing to effort leads to less positive emotions and a higher persistence. Finally, as predicted persistence is related to performance.

Contrary to our expectations, however, attributions have, in the case of easy tasks, after entering all the other variables in the equation still a direct effect on persistence and on performance, while the predicted indirect effect of expectations of success on persistence is absent.

After a difficult task most of the effects are non-significant. Remarkably, aside from persistence effects, a direct effect of attributions 
is found on all performance variables similar to the effect found after an easy task.

\subsection{Discussion}

Previous experiments have failed to show effort attributions to be better than other attributions in terms of performance. Two possible answers to the question why previous experiments failed to show this beneficiallity were put forward.

The first explanation, the social facilitation hypothesis, presumes that attributions have different effects as a function of the difficulty level of the task. The second explanation, the attributional hypothesis, assumes that emotions elicited by effort attributions have a debilitating effect while making complex tasks which counteracts the beneficial effect of working harder. Both explanations predict the same effect after an easy task. An attribution to effort will lead to a higher expectation of success, ${ }_{r}$ persistence and performance than an attribution to the combination of effort and task difficulty which in turn will lead to a higher expectation of success, persistence and performance than an attribution to task difficulty alone. After complex tasks, however, the predictions of both explanations differ. The social facilitation hypothesis predicts a similar effect on expectation of success and persistence as after easy tasks but, expects that the less people attribute to effort the better they will perform. The attributional hypothesis, however, predicts that after complex tasks an attribution to the combination of effort and task difficulty will lead to less intense emotions and, as a consequence of these emotions, to a better performance than an attribution to effort alone. An attribution to task difficulty alone will lead to even less intense emotions but not to better performance.

With regard to these hypotheses it can be stated that the results of this experiment seem to favor neither of the two hypotheses. Whereas differential effects after different tasks only were predicted on performance variables it seems to be that differential effects are also found on expectation of success, and persistence. Although this result is not expressed in significant interaction effects, the effects of attributional manipulations are small or absent if subjects made a difficult task. After making an easy task, however, it is found that attributing to effort or the combination of effort and task difficulty results in a higher expectation of success and persistence than attributing to task difficulty alone. Subjects not only seem more likely to increase their persistence whenever they feel they are working on an easy task as opposed to a difficult task, but their performance seems to be affected 
and they also seem to adjust their expectation of success. These results already provide a partial answer to the question of why effort attributions result in highest performance.

Results of secondary analyses, however, revealed that, despite an increased persistence, subjects in the combination condition will give more incorrect answers than subjects in the effort only condition. It seems as if the effort manipulation not only increases persistence but also heightens accuracy, something the combined attribution did not do. The effort attribution not only affects the quantity of work, but the quality of work as well. This is confirmed by the regression analyses, where it is found that the positive effect of attributing to effort, while making easy tasks, consists of a persistence, an emotion and a direct effect. The emotional effect is masked by the fact that the attribution leading to the highest persistence, effort, also evolkes less positive emotions. The remaining direct effect of attributions can, by elimination, only be an effect of enhanced concentration due to attributing to effort. An attribution to task difficulty and effort combined affects the quantity only. An explanation for this result might be that an attribution to effort, because it is more controllable than an attribution to the combination of effort and task difficulty, leaves the subjects subjectively more room for initiative than an attribution to effort and task difficulty. The idea that the task is very difficult leads to harder work if it is combined with lack of effort. It might, however, also inhibit thinking about coping strategies with this kind of difficult task, something an attribution to effort only leaves more room for. One way to improve the effects of the combined attribution might be by presenting task difficulty as unstable (see Wilson \& Linville, 1982, 1985). If task difficulty is perceived as unstable, subjects will probably feel more confident, invest more effort and improve their performance.

By now it becomes clear that the results of this experiment clearly favor the original predictions of attribution theory (Weiner, 1985, 1986) and their applications in reattribution training (Försterling, 1985, 1988). Effort is, compared with an attribution to task difficulty, the attribution which leads to the highest expectation of success, persistence and performance. The combined attribution of effort and task difficulty is as good as an attribution to effort alone with regard to expectation of success and persistence, but not, however, with regard to performance. Regression analyses furthermore showed that the attributional model formulated by Weiner $(1985,1986)$ fits the data fairly accurate in the case of easy tasks. Aside from direct influences of differences in attributions on performance and the absence off a path between expectation of success and persistence, no inconsistent 
results are found. After difficult tasks, however, the results do not fit within the attributional model.

The data suggest that the difference in the fit of the attributional model between easy and difficult task is largely due to the difference in the relation between persistence and performance. Easy tasks, show an increased performance with an increased persistence, while difficult tasks do not show this relation. This implies that the persistence component, by far the best predictor of performance, of attributing to effort can not work in the case of difficult tasks. Consequently it seems best to limit attributional interventions to those kind of tasks of which performance has a clear persistence component. 



\section{References}

Anderson, C.A. (1983). Motivational and performance deficits in interpersonal setting: The effect of attributional style. Joumal of Personality and Sacial Psychology, 45, 1136-1147.

Andrews, G.R., \& Debus, R.L. (1978). Persistence and the causal perception of failure: Modifying cognitive attributions. Joumal of Educational Psychology, 70, 154-166.

Bandura, A., \& Wood, R. (1989). Effect of perceived controllability and performance standards on self-regulation of complex decision making. Joumal of Personality and Social Psychology, 56, 805-814.

Beck, A.T. (1967). Depression: Clinical, experimental and theoretical aspects. New York: Harper Row.

Beck, A.T. (1976). Cognitive therapy and the emotional disorders. New York: International Universities Press.

Berscheid, E., Graziano, W., Monson, T., \& Dermer, M. (1976). Outcome dependency: Attention, attribution and attraction. Joumal of Personality and Social Psychology, 34, 978-989.

Bohner, G., Bless, H., Schwarz, N., \& Strack, F. (1988). The impact of valence and subjective probability. European Joumal of Social Psychology, 18, 335-346.

Brown, J., \& Weiner, B. (1984). Affective consequences of ability versus effort ascriptions: Controversies, resolutions and quandaries. Joumal of Educational Psychology, 76, 146-158.

Cervone, D., Jiwani, N., \& Wood, R. (1991). Goal setting and the differential influence of self-regulatory processes on complex decision-making performance. Joumal of personality and Social Psychology, 61, 257-266.

Chapin, M., \& Dyck, D.G. (1976). Persistence in children's reading behavior as a function of n-length and attribution retraining. Joumal of Abnomal Psychology, 85, 511-515.

Clifford, M.M. (1986). The comparative effects of strategy and effort attributions. British Joumal of Educational Psychology. 56, 75-83.

Clifford, M.M. (1986 b). The effects of ability, strategy and effort attributions for educational, business and athletic failure. British Journal of Educational Psychology, 56, 169-179.

Covington, M.V., \& Omelich, C.L. (1979 ). Effort: The double-edged sword in school achievement. Joumal of Educational Psychology, 71 , 169-182. 
Covington, M.V., \& Omelich, C.L. $\left(1979^{b}\right)$. It's best to be able and virtuous too: Student and teachers evaluative responses to successful effort. Journal of Educational Psychology, 71, 688-700.

Covington, M.V., \& Omelich, C.L. (1979'). Are causal attributions causal? A path analysis of the cognitive model of achievement motivation. Jountal of Personality and Social Psychology, 37, 14871504.

Covington, M.V., \& Omelich, C.L. (1984). Controversies or consistencies? A reply to Brown and Weiner. Joumal of Educational Psychology, 76, 159-168.

Darley, J.M., \& Goethals, G.R. (1980). People's analyses of the causes of ability-linked performances. In L. Berkowitz (Ed.), Advances in Experimental Social Psychology (Vol. 13). New York: Academic Press. Den Boer, D.J., Kok, G.J., Hospers, H.J., Gerards, F., \& Strecher, V.J. (1991). Health education strategies for attributional retraining and self-efficacy improvement. Health Education Research, 6, 239248.

Den Boer, D.J., Kok, G.J., Van Knippenberg, A.F.M., \& Peeters, L. (1991). Attributie aan schuld en de houding tegenover AIDSpatiënten; een vergelijking tussen Aids en andere ziekten. Nederlands Tijdschrift voor de Psychologie, 46, 216-225.

Den Boer, D.J., Meertens, R., \& Kok, G.J. (1989). De relatie tussen attributie theorie en cognitieve therapieën. In A.P. Buunk, \& A.J. Vrugt (Red.), Sociale psycholgie \& Klinische problemen (pp. 157-187). Assen: Dekker \& Van de Vegt.

Den Boer, D.J., Meertens, R.M., Kok, G.J., \& Van Knippenberg, A.F.M. (1989). Measurement effects in reattribution research. European Joumal of Social Psychology, 19, 553-559.

Den Boer, D.J., Meertens, R.M., Kok, G.J., \& Van Knippenberg, A.F.M. (submitted). Effects of differences on attributional dimensions on cognitions and behaviour.

Dweck, C.S. (1975). The role of expectations and attributions in the alleviation of learned helplessness. Joumal of Personality and Social Psychology, 36, 451-462.

Eiser, J.R., \& Van Der Pligt, J. (1986). Smoking cessation and smokers' perceptions of their addiction. Joumal of Social and Clinical Psychology, 4, 60-70.

Eiser, J.R., Van Der Pligt, J., Raw, M., \& Sutton, S. (1985). Trying to stop smoking: Effects of perceived addiction, attributions for failure, and expectancy of success. Joumal of Behavioral Medicine, 8, 321-341.

Ellis, A. (1962). Reason and emotion in psychotherapy. New York: Lyle Stuart Press. 
Festinger, L. (1954). A theory of social comparison processes. Human Relations, 57, 271-282.

Fiske, S.T., \& Taylor, S.E. (1984). Social Cognition. Reading, MA: Addison Wesley.

Försterling, F. (1985). Attributional retraining: A review. Psychological Bulletin, 98, 495-512.

Försterling, F. (1986). Attributional conceptions in clinical psychology. American Psychologist, 41, 275-285.

Försterling, F. (1988). Attribution theory in clinical psychology. New York: Wiley.

Fowler, J.W., \& Peterson, P.L. (1981). Increasing reading persistence and altering attributional style of learned helpless children. Joumal of Educational Psychology, 73, 251-260.

Gerards, F.M., \& Hospers, H.J. (1991). Health counseling. Een strategie voor het individueel begeleiden van adviezen. Nederlands Tijdschrift voor Diëtisten, 46, 132-137.

Haisch, J., Rduch, G., \& Haisch, I. (1985). Längerfristige Effekte attributionstherapeutischer Massnahmen bei Übergewichtigen: Auswirkungen eines Attributionstrainings auf Abnehmerfolg und Abbrecherquote bei einem 23wöchigen Gewichtsreduktions-Programm. Psychotherapie und medizische Psychologie, 35, 133-140.

Harvey, J.H., \& Weary, G. (1984). Current issues in attribution theory and research. Annual Review of Psychology, 35, 427-459.

Heider, F. (1958). The psychology of interpersonal relations. New York: Wiley.

Hewstone, M. (1989). Catisal attribution: From cognitive processes to collective beliefs. Oxford: Blackwell.

Hewstone, M., \& Antaki, C. (1988). Attribution theory and social explanations. In M. Hewstone, W. Stroebe, J.P. Codol, \& G.M. Stephenson (Eds.), Introduction to social psychology; a european perspective (pp. 111-141). Oxford: Blackwell.

Hospers, H.J., Kok, G.J., \& Strecher, V.J. (1990). Attributions for previous failures and subsequent outcomes in a weight reduction program. Health Education Quarterly, 17, 409-415.

Kahneman, D. (1973). Attention and Effort. Englewood Cliffs, NJ: Prentice Hall.

Kelley, H.H. (1967). Attribution theory in social psychology. In D. Levine (Ed.), Nebraska symposium on motivation (Vol. 15) (pp. 192240). Lincoln: University of Nebraska Press.

Kelley, H.H. (1972). Causal schemata and the attribution process. In E.E. Jones, D.E. Kanouse, H.H. Kelley, R.E. Nisbett, S. Valins, \& B. Weiner (Eds.), Attribution: Perceiving the causes of behavior (pp. 151-174). Morristown, NJ: General Learning Press. 
Kelley, H.H., \& Michela, J.L. (1980). Attribution theory and research. Annual Review of Psychology, 31, 457-503.

Kernis, M.H., Zuckerman, M.s \& McVay, E. (1988). Motivational factors affecting performance: The impact of perceived locus of causality. Personality and Social Psychology Bulletin, 3, 524-535.

Kok, G.J, Den Boer, D.J., De Vries, H., Gerards, F., Hospers, H.J., \& Mudde, A.N. (in press). Self efficacy and attribution theory in health education. In R. Schwarzer (Ed.), Social cognitive mediators of action: The role of expectancies.

Long, G.M. (1980). Iconic memory: A review and critique of the study of short-term visual storage. Psychological Bulletin, 88, 785820.

Manstead, A.S.R., \& Semin, G.R. (1980). Social facilitation effects: mere enhancement of dominant responses? British Joumal of Social and Clinical Psychology, 19, 119-136.

Marlatt, G.A., \& Gordon, J.R. (1985). Relapse prevention. Maintenance strategies in the treatment of addictive behaviors. New York: Guilford.

McFarland, C., \& Ross, M. (1982). Impact of causal attributions on affective reactions to success and failure. Joumal of Personality and Social Psychology, 43, 937-946.

McMahan, I.D. (1973). Relationships between causal attributions and expectancy of success. Journal of Personality and Social Psychology, $28,108-114$.

Medway, F.J., \& Venino, G.R. (1982). The effects of effort feedback and performance patterns on children's attributions and task persistence. Contemporary Educational Psychology, 7, 26-34.

Neale, J.M., \& Friend, R.M. (1972). Attributional determinants of reactions to performance in academic situations. Perceptual and Motor Skills, 34, 35-40.

Paulus, P.B. (1983). Group influence on task performance and informational processing. In P.B. Paulus (Ed.), Basic Group Processes. New York: Springer Verlag.

Pruitt, D.J., \& Insko, C.A. (1980). Extension of the Kelley attribution model: The role of comparison-object consensus, target-object consensus, distinctiveness, and consistency. Joumal of Personality and Social Psychology, 39, 39-58.

Pyszczynski, T.A., \& Greenberg, J. (1981). Role of disconfirmed expectancies in the instigation of attributional processing. Joumal of Personality and Social Psychology, 40, 31-38.

Pyszczynski, T.A., \& Greenberg, J. (1987). Toward an integration of cognitive and motivational perspectives on social inference: $A$ biased hypothesis-testing model. In L. Berkowitz (Ed.), Advances in experimental social psychology (Vol. 20) (pp. 297-340). San Diego, CA: Academic Press. 
Riemer, B.S. (1975). Influence of causal beliefs on affect and expectancy. Joumal of Personality and Social Psychology, 31, 1163-1167.

Rijsman, J.B. (1980). Sociale vergelijking. Een theoretische analyse. In J.B. Rijsman, \& H.A.M. Wilke (Red). Sociale vergelijkingsprocessen; Theorie en onderzoek. Deventer; Van Loghum Slaterus.

Rosenbaum, R.M. (1972). A dimensional antalysis of the perceived causes of success and failure. Unpublished doctoral dissertation, University of California, Los Angeles.

Ross, M., \& Fletcher, G.J.O. (1985). Attribution and social perception. In G. Lindzey, \& E. Aronson (Eds.), Handbook of Social Psychology Volume II: Special Fields and Applications (pp. 73-122). New York: Random House.

Rotter, J.B. (1966). Generalized expectancies for internal versus external control of reinforcement. Psychological Monographs, 80, (1, Whole No. 609).

Russell, D. (1982). The causal dimension scale: A measure of how individuals perceive causes. Joumal of Personality and Social Psycho$\log y, 42,1137-1145$.

Russell, D., \& McAuley, E. (1986). Causal attributions, causal dimensions and affective reactions to success and failure. Joumal of Personality and Social Psychology, 50, 1174-1185.

Russell, D.W., McAuley, E., \& Tarico, V. (1987). Measuring causal attributions for success and failure: $\mathrm{A}$ comparison of methodologies for assessing causal dimensions. Joumal of Personality and Social Psychology, 52, 1248-1257.

Schunk, D.H. (1981). Modelling and attributional effects on children's achievement: A self-efficacy analysis. Journal of Educational Psycho$\log y, 73,93-105$.

Schunk, D.H. (1982). Effects of effort attributional feedback on children's perceived self-efficacy and achievement. Joumal of Educational Psychology, 74, 548-556.

Schunk, D.H. (1983). Ability versus effort attributional feedback: Differential effects on self-efficacy and achievement. Journal of Educational Psychology, 75, 848-856.

Schunk, D.H. (1984). Sequential attributional feedback and children's achievement behaviors. Joumal of Educational Psychology, 76, 11591169.

Tabachnick, B.G., \& Fidell, L.S. (1989). Using Multivariate Statistics (2nd ed.). New York: Harper \& Row.

Van Knippenberg, A.F.M., Willke, H.A.M., \& De Vries, N.K. (1981). Social comparison on two dimensions. European Journal of Social Psychology, 11, 267-283.

Weary, G., Stanley, M.A., \& Harvey, J.H. (1989). Attribution. New York: Springer Verlag. 
Weiner, B. (1979). A theory of motivation for some classroom experiences. Joumal of Educational Psychology, 71, 3-25.

Weiner, B. (1983). Some methodological pitfalls in attributional research. Joumal of Educational Psychology. 75, 530-543.

Weiner, B. (1985). An attributional theory of achievement motivation and emation. Psychological Review, 92,548-573.

Weiner, B. (1986). An attributional theory of motivation and emotion. New York. Springer Verlag.

Weiner, B, Frieze, 1., Kukla, A., Reed, L., Rest, S., \& Rosenbaum, R.M. (1971). Perceiving the causes of success and failure. In E.E. Jones, D.E. Kanouse, H.H. Kelley, R.E. Nisbett, S. Valins, \& B. Weiner (Eds.), Attribution: Perceiving the causes of behavior (pp. 95120). Morristown, NJ: General Learning Press.

Weiner, B., Nierenberg, R., \& Goldstein, M. (1976). Social learning (locus of control) versus attributional (causal stability) interpretations of expectancy of success. Journal of Personality, 44, 52-68.

Weiner, B., Russell, D., \& Lerman, D. (1978). Affective consequences of causal ascriptions. In J.H. Harvey, W.J. Ickes, \& R.F. Kidd (Eds.), New directions in attribution research (Vol. 2) (pp. 59-88). Hillsdale, NJ: Erlbaum.

Weiner, B., Russell, D., \& Lerman, D. (1979). The cognition-emotion process in achievement related contexts. Joumal of Personality and Social Psychology, 37, 1211-1220.

Wilke, H.A.M., \& Van Knippenberg, A.F.M. (1988). Group Performance. In M. Hewstone, W. Stroebe, J.P. Codol, \& G.M. Stephenson (Eds:), Introduction to Social Psychology; A European Perspective (pp. 315-349). Oxford: Blackwell.

Wilson, T.D., \& Linville, P.W. (1982). Improving the academic performance of college freshmen: Attribution therapy revisited. Joumal of Personality and Social Psychology, 42, 367-376.

Wilson, T.D., \& Linville, P.W. (1985). Improving the performance of college freshmen with attributional techniques. Joumal of Personality and Social Psychology, 49, 287-293.

Wong, P.T., \& Weiner, B. (1981). When people ask 'why' questions and the heuristics of attributional search. Joumal of Personality and Social Psychology, 40, 650-663.

Wood, R., \& Bandura, A. (1989). Impact of conceptions of ability on self-regulatory mechanisms and complex decision making. Joumal of Personality and Social Psychology, 56, 407-415.

Zajonc, R.B. (1965). Social facilitation. Science, 149, 269-274. 


\section{Summary}

In reattribution programs it is assumed that causes people hold responsible for an outcome determine reactions when the same task has to be made again (Försterling, 1985; Weiner, 1985). Changes in perceived causes for previous performances are expected to result in changes in emotions people experience, the way they expect to perform on comparable tasks in the future and how they actually perform on these tasks. Central topic of this thesis is an analysis of the ideas underlying reattribution practice.

Because Weiner's attribution theory is the basis of most reattribution interventions, chapter 1 (the overview) starts, after presenting the general subject of this thesis, with a discussion of this theory. Weiner's theory is concerned with relations between attributions, emotions, cognitions and behavior. Because it states that not the causes itself, but how these causes are positioned on the dimensions of stability, internality and controllability, are responsible for effects on cognitions, emotions and behavior, research and theory on the dimensionality of causes is discussed first. Second, attention is paid to how attribution theory expects differences in stability to influence expectations of success. After failure, stable attributions lead to lower expectations of success than unstable attributions. After success, however, stable attributions lead to higher expectations of success than unstable attributions. Expectations of success in turn are related to behavior. The higher one's expectation of success the higher one"s persistence on a task, and the better one's performance. Apart from this 'cognitive' relation between attributions and behavior, attribution theory also proposes an 'emotional' link between attributions, emotions and behavior. Differences in internality and controllability are supposed to lead to differences in emotional reaction to an outcome. Internal, controllable attributions for failure, for instance, lead to guilt while internal, uncontrollable attributions for failure lead to shame. Guilt is assumed to be a motivating emotion, and would lead to improved performance, while shame is a debilitating emotion and would lead to deteriorated task performance.

Reattribution interventions try to induce people to explain their previous performances in such a way that an attribution is made which ensures confidence, feelings of control and persistence. In reattribution interventions lack of effort is selected most often in the case of failure. Attributing failure to effort, an unstable, internal and controllable cause, should lead to relatively high expectations of 
success, high persistence, motivating emotions and thus performance enhancement. Although reattribution studies have been employed in many different problem areas and are generally successful, an examination of the literature reveals that some fundamental ideas on which reattribution practice is based, have not been examined. Three of these ideas are discussed.

First, it is noted that attribution theory is extensively investigated but hardly any research has been done on the consequences of attributions made for own, actually experienced, success or failure. Experiments conducted until now have not been concerned with investigating causal relations between attributions made for own performance, and consequent expectation of success, emotions, behavior and performance. For reattribution practice, the causality of the relations between attributions on the one hand and cognitions, emotions, behavior, and performance on the other, are of utmost importance: reattribution interventions will only work when reattribution of own performance on a task will cause better performance.

Second, it is shown that it is possible to formulate an alternative explanation for the beneficial effects on performance of attributing failure to effort, than is assumed in reattribution practice. The studies done on reattribution do not exclude the possibility that the positive effects of the intervention are due to measurement effects. In general the intervention is confounded with making subjects fill in attributional questionnaires. Measuring attributions makes subjects explicitly consider causes for their success or failure. Together with the fact that thinking about causes provides one with the possibility of control, it may be expected that measuring attributions will have a positive effect on performance.

Finally, based on a discussion of lacunae in the literature, it is suggested that reattribution interventions only work under certain conditions. Research and theory on social facilitation and inhibition suggests that given complex tasks effort attributions for failure might, due to the associated emotions, lead to deterioration of task performance. The linking of social facilitation and attribution theory leads to the suggestion that beneficial effects on persistence of attributing failure to effort are dampened by emotional effects. In the case of complex tasks there might be attributions which are more beneficial to performance than attributing to lack of effort.

The three questions, implicitly formulated above, are addressed in the experiments reported in this thesis. Whereas chapter 1 discusses the broad outline and main results of these experiments, the chapters 2,3 and 4 discuss these experiments in detail. 
measuring attributions for success and failure has an effect on performance. In this study subjects either experienced success or failure and had, or had not, to fill in an attributional questionnaire. Before and after these manipulations subjects made a similar task. Difference in performance was the dependent variable.

Results of this experiment indicate that measuring attributions after failure has a positive effect on performance. After success however no differences between the measurement and no-measurement condition are found. It is concluded that the effects of reattribution studies are at least partly due to a measurement effect. Secondary analyses revealed that attributing failure to task difficulty is related to performance enhancements. Attribution of failure on the first task to task difficulty, may have made subjects recognize that they should, in order to succeed, invest more effort in the second task.

Two experiments focusing on causal relations in attribution theory are reported in chapter 3 . Both experiments consisted of 8 conditions. Subjects experienced success or failure, and were induced to attribute their (manipulated) outcome to internal unstable, internal stable, external unstable or external stable causes. Expectations of success; and differences in persistence and performance served as dependent measures.

Results of both experiments support the relation proposed in attribution theory between stability of attributions and expectation of success. Only after failure, though, the predicted effect is found that stable attributions lead to lower expectations of success than unstable attributions. Based on these data it is concluded that, because attributions were manipulated, stability of attributions causes differences in expectations of success. After success, the effect is in the predicted reversed direction but fails to approach significance. It is furthermore found, in both experiments, that differences in controllability, unexpectedly, have an effect on expectations of success. In a sense this is intuitively plausible: instability implies the possibility of change, but not whether or not this change will be beneficial. Controllability, though, implies control over the direction of change. Results with regard to behavioral measures are less encouraging. Effort is not found to be the attribution most beneficial to persistence and performance.

The fourth experiment (chapter 4) finally, is concerned with the ideas generated by social facilitation theory. In this experiment subjects experienced failure on either easy or complex tasks, and were induced to attribute their performance to either lack of effort, to the difficulty of the task or to the combination of effort and difficult tasks. After these manipulations subjects performed a similar task. In this 
experiment expectations of success, persistence, emotions and performance figured as dependent variables.

Analyses of the data of this experiment, seem to reveal that, in general, attributional effects are found for easy, but not for complex tasks. Attributions to the combination of effort and task difficulty or effort alone lead to the highest expectation of success and persistence. Attributions to effort, however, lead to more performance enthancement than other attributions. This beneficial effect of attributing failure to effort seems to be due to three different effects. Attributing failure to effort leads to a higher persistence, which, in the case of easy tasks leads to a higher performance. After this effect is taken into account, there is a negative effect of attributing to effort via emotions on performance. The idea of a dampening emotional effect thus seems to have some merit. Finally it is found that attributing to effort has a direct effect on performance. Because persistence and emotional effects are already taken into account this must be an effect caused by an improvement of the quality of performance (e.g. better concentration). Thus, attributing to effort not only seems to lead to a higher persistence, but also to an increase in the quality of performance.

After summarizing the experiments and the main results, chapter 1 continues with a general discussion. In this discussion implications for attribution theory and reattribution practice are discussed. With regard to the practice of reattribution it is noted that the idea of making people attribute their failures to effort received support. Methods to change people's attributions about real life events, however, need more attention. It is suggested that, when reattribution interventions are to be used in real-life situations, they shoull be incorporated in interventions based on broader theories (e.g. "Relapse Prevention' or 'Health Counseling' theories).

With regard to attribution theory it is stated that the research presented in this thesis has supported the ideas of Weiner. No important contradictions with attribution theory were found. To some extent the beneficiallity of attributing failure to effort, seems to be due to encouraging subjects to think about causes, but also to a heightened persistence and concentration effect. The most important deviation from attribution theory is that attributional effects after success were not found. In case of a complex task or situations when less positive emotions are evoked, the effectiveness of effort attributions seems to be reduced. It should be clear, however, that this does not lead to negative effects of attributing failure to effort. The relation consistently found between controllability of attributions and expectation of success are plausible, and it may be useful to incorporate this relation in attribution theory. 


\section{Samenvatting}

In herattributie interventies wordt ervan uitgegaan dat de oorzaken, die mensen als verantwoordelijk zien voor een bepaalde uitkomst, bepalen hoe men een volgende keer op eenzelfde taak zall reageren (Försterling, 1985; zie ook Weiner, 1985). Een verandering in waargenomen oorzaak van eerdere prestaties wordt verondersteld tot veranderingen te leiden in emotionele reactie "verwachtingen over hoe men in de toekomst zal reageren en daadwerkelijke prestatie. In dit proefschrift staat een analyse centraal van de ideeën, waarop deze herattributie interventies gebaseerd zijn.

Aangezien Weiners attributietheorie de basis is van de meeste herattributie-interventies begint hoofdstuk 1 dan ook, nadat het onderwerp van dit proefschrift geintroduceerd is, met een bespreking van deze theorie. Weiners theorie beschrijft relaties tussen oorzaken, emoties, cognities en gedrag. Aangezien deze theorie ervan uitgaat dat niet zozeer de oorzaken zelf, maar hoe deze oorzaken gepositioneerd worden op de dimensies internaliteit, stabiliteit en controleerbaarheid, effecten veroorzaken op emoties, cognities en gedrag, wordt eerst de theorie en onderzoek over deze dimensionaliteit van oorzaken beschreven. In de tweede plaats wordt er aandacht besteed aan hoe in attributietheorie verwacht wordt dat verschillen in stabiliteit van oorzaken tot verschillen in succesverwachting leiden. Na falen leiden stabiele attributies tot lagere succesverwachtingen dan instabiele attributies. Na succes zou dit effect echter omgekeerd moeten zijn: stabiele attributies voor succes leiden tot hogere succesverwachtingen dan instabiele attributies voor succes. Vervolgens wordt verondersteld dat hoe hoger iemands succeswerwachting is, des te meer die persoon bereid is om door te werken aan een taak en des te beter de prestatie op de taak zal zijn. Naast deze 'cognitieve' relatie tussen attributies en gedrag, wordt in deze theorie nog een 'emotionele relatie tussen attributies, emoties en gedrag verondersteld. Verschillen in internaliteit en controleerbaarheid van attributies worden verondersteld tot verschillen in emotionele reactie, naar aanleiding van een uitkomst, te leiden. Interne, controleerbare attributies voor falen leiden, volgens de theorie, tot schuld. Interne, oncontroleerbare attributies voor falen leiden daarentegen tot schaamte. Van schuld wordt nu verondersteld dat het een motiverende emotie is, en dus tot betere prestaties leidt. Schaamte, daarentegen, zou een demotiverende emotie zijn en tot slechtere prestaties leiden. 
Herattributie-interventies proberen mensen zover te krijgen dat zij hun eerdere prestaties op zo'n manier attribueren dat zelfvertrouwen, een idee van controle en persistentie, het gevolg zijn. In het geval van falen wordt meestal gekozen voor een attributie aan te weinig inzet. Inzet, of gebrek aan inzet, is een instabiele, interne en controleerbare oorzaak en zal dus leiden tot een hoge succeswerwachting, een hoge persistentie, motiverende emoties en, als een gevolg hiervan, verbetering van prestatie. Alhoewel herattributie-interventies op veel verschillende problemen zijn toegepast en over het algemeen succes hebben, laat een bestudering van de literatuur toch zien dat over een aantal fundamentele vragen weinig onderzoek gedaan is. Drie van deze vragen worden bediscussieerd.

In de eerste plaats wordt gesignaleerd dat er veel onderzoek naar attributietheorie is gedaan, maar dat er bijna geen aandacht besteed is aan wat de consequenties zijn van verschillende attributies, die men maakt voor echt, zelf meegemaakt succes of falen. Onderzoek heeft zich tot nu toe nauwelijks gericht op het vaststellen of toetsen van de veronderstelde causale verbanden tussen attributies, gemaakt voor eigen prestatie, en daaropvolgende succesverwachtingen, emoties, gedrag en prestatie. Voor de toepassing van attributie theorie is het natuurlijk van belang om te weten of een herattributie van de eigen prestatie inderdaad tot verschillen in prestatie leidt.

In de tweede plaats wordt er aangegeven dat het mogelijk is om een alternatieve verklaring te formuleren, in plaats van de gangbare verklaring in herattributie-toepassingen, voor de eerder gevonden positieve effecten van het attribueren van falen aan gebrek aan inzet. Studies naar herattributie laten namelijk de mogelijkheid open dat deze positieve effecten van de interventie veroorzaakt worden door meeteffecten. In het algemeen krijgen proefpersonen in de experimentele conditie zowel een attributie-training als een attributie-vragenlijst, om de interventie te controleren. Het meten van attributies zorgt ervoor dat proefpersonen expliciet gaan nadenken over de oorzaken van hun succes of falen. Als in aanmerking wordt genomen dat het denken over oorzaken de mogelijkheid tot controle kan geven, is het aannemelijk om te veronderstellen dat het meten van attributies, op zichzelf, een positief effect op prestatie zal hebben.

Tenslotte wordt gesuggereerd dat herattributie-interventies alleen onder bepaalde condities werken. Onderzoek en theorie op het gebied van sociale facilitatie en inhibitie geeft aan dat, indien complexe taken gemaakt moeten worden, inzet-attributies voor falen, door de geassocieerde emoties, wel eens negatieve effecten zouden kunnen hebben. Door inzichten uit deze sociale facilitatie theorie te combineren met inzichten uit de attributietheorie, kan verondersteld worden dat de positieve effecten van attributies voor falen aan gebrek 
aan inzet afgezwakt worden door een emotioneel effect. In het geval van falen op complexe taken zouden ex zelfs attributies kunnen zijn die betere effecten op gedrag hebben dan gebrek aan inzet.

Deze drie vragen, hierboven aangegeven, worden onderzocht in de experimenten, gerapporteerd in dit proefschrift. Hoofdstuk 1 behandelt de grote lijnen en belangrijkste resultaten van deze experimenten. In hoofdstuk 2,3 en 4 wordt uitgebreid op de verschillende experimenten ingegaan.

Het eerste experiment (zie hoofdstuk 2), onderzoekt of er effecten zijn van het meten van attributies op prestatie. In deze studie maakten proefpersonen een taak naar aanleiding waarvan zij succes- of faalfeedback kregen. Verder kreeg de helft van de proefpersonen wel een attributie-vragenlijst om in te vullen en de andere helft niet. Voor en na deze manipulaties werd eenzelfde soort taak gemaakt. Verschil in prestatie was de afhankelijke variabele.

De resultaten van dit experiment geven aan dat het meten van attributies, gemaakt voor falen, een positief effect heeft op prestatie. Na succes werd echter geen verschil tussen de twee condities gevonden. Er wordt geconcludeerd dat de effecten van herattributie interventies, op zijn minst gedeeltelj $k$, verklaard kunnen worden door een meeteffect. Secundaire analyses laten zien dat het attribueren van fallen aan taak moeilijkheid is gerelateerd aan prestatieverbeteringen. Attributie van falen op de eerste taak aan taakmoeilijkheid, zou proefpersonen er toe hebben kunnen brengen om zich te realiseren dat, om succes te behalen, zij meer inzet in de tweede taak moeten investeren.

Twee experimenten, gericht op de causaliteit van relaties in attributietheorie, worden gerapporteerd in hoofdstuk 3. Beide experimenten bestonden uit dezelfde 8 condities. Proefpersonen kregen succes- of faalfeedback, naar aanleiding van een taak die zij gemaakt hadden, en werd verteld dat dit door (gebrek aan) inzet, (gebrek aan) capaciteiten, (moeilijke) gemakkelijke taken of (pech) geluk kwam. Succesverwachting en verschillen in persistentie en prestatie waren afhankelijke variabelen.

De resultaten van beide experimenten ondersteunen de causale relatie, verondersteld in attributietheorie, tussen stabiliteit van attributies en succesverwachting. Alleen na falen wordt echter het verwachte effect gevonden dat stabiele attributies tot een lagere succesverwachting leiden dan instabiele attributies. Omdat attributies gemanipuleerd waren wordt dus geconcludeerd dat stabiliteit van attributies verschillen in succesverwachting veroorzaakt. $\mathrm{Na}$ succes wordt een effect in de voorspelde tegengestelde richting gevonden 
wat echter niet significant is. Verder laten beide experimenten, onverwacht, zien dat verschillen in controleerbaarheid een effect hebben op succesverwachting. Intuitief is dat goed te begrijpen. Instabiliteit impliceert veranderbaarheid maar niet of deze verandering positief zal zijn. Controleerbaarheid, daarentegen, betekent controle over de richting van de verandering. De resultaten met betrekking tot de gedragsmaten waren minder veelbelovend. Inzet, of gebrek aan inzet, is niet de attributie die de meest positieve effecten op persistentie en prestatie heeft.

Het vierde experiment (hoofdstuk 4), tenslotte, richt zich op de ideeên, geinspireerd door de sociale facilitatie theorie. In dit experiment kregen proefpersonen faalfeedback over gemakkelijke of moeilijke taken. Verder werd gezorgd dat dit falen werd toegeschreven aan gebrek aan inzet, moeilijkheid van de taak of een combinatie van deze twee oorzaken. Na deze taken moest eenzelfde taak opnieuw gemaakt worden. Succesverwachting, persistentie, emoties en prestaties werden als afhankelijke variabele gemeten.

Analyse van de data van dit experiment lijkt aan te tonen dat, in het algemeen, attributie-effecten gevonden worden voor gemakkelijke maar niet voor moeilijke taken. Toeschrijven van falen aan de combinatie van gebrek aan inzet en taakmoeilijkheid of gebrek aan inzet alleen leidt tot de hoogste succesverwachting en persistentie. Proefpersonen in de inzet-conditie daarentegen, lieten meer prestatieverbetering zien dan proefpersonen in andere condities. Dit positieve effect van attribueren van falen aan een gebrek aan inzet lijkt veroorzaakt te worden door drie verschillende factoren. Het attribueren van falen aan gebrek aan inzet leidt tot een hogere persistentie wat, in het geval van makkelijke taken, tot een hogere prestatie leidt. Als er gecorrigeerd is voor dit effect, is er nog een negatief elfect van het attribueren aan gebrek aan inzet; via emoties, op prestatie. Het idee van een negatief emotioneel effect vindt dus enige ondersteuning. Tenslotte wordt er nog gevonden dat attribueren aan gebrek aan inzet een direct effect op prestatie heeft. Aangezien persistentie- en emotieeffecten al in aanmerking zijn genomen moet dit effect te maken hebben met de kwaliteit van prestatie, bijvoorbeeld een betere concentratie. Falen attribueren aan gebrek aan inzet leidt dus, niet alleen tot een hogere persistentie, maar ook tot een verbetering van de kwaliteit van prestatie.

Nadat de experimenten en de belangrijkste resultaten hiervan zijn samengevat, vervolgt hoofstuk 1 met een algemene discussie. In deze discussie worden implicaties voor attributietheorie en de toepassing van herattributie-trainingen besproken. Met betrekking tot deze 
toepassing wordt gesuggereerd dat het idee om mensen hun falen aan een gebrek aan inzet te laten attribueren, ondersteuning krijgt. Methoden om buiten het laboratorium attributies te veranderen verdienen echter meer onderzoek. In dit soort situaties zouden herattributie-interventies gebaseerd moeten worden op meer algemene theorieën (bijvoorbeeld "Relapse Prevention" of "Health Counseling" theorieën).

Met betrekking tot de attributietheorie wordt gesteld dat het onderzoek, gerapporteerd in dit proefschrift, de ideeên van Weiner ondersteunt. Belangrijke afwijkingen zijn niet gevonden. Tot op zekere hoogte lijkt het effect van herattributie-interventies verklaarbaar doordat proefpersonen nadenken over oorzaken, maar ook door een verhoogde persistentie en concentratie. De belangrijkste gevonden afwijking van attributietheorie is het ontbreken van effecten van attributies na succes. In het geval van complexe taken of situaties waarin minder positieve emoties worden opgeroepen, lijkt het effect van herattributie iets minder duidelijk. De, herhaaldelijk gevonden, relatie tussen controleerbaarheid van attributies en succesverwachting is goed te verklaren en het zou waardevol kunnen zijn om deze relatie in attributietheorie op te nemen. 


\section{Curriculum vitae}

Dirk-Jan den Boer werd op 13 april 1963 in Eindhoven geboren. In 1981 behaalde hij het VWO diploma aan het Dr. Nassau College in Assen. In datzelfde jaar begon hij zijn studie Psychologie aan de Rijksuniversiteit Groningen. In 1987 heeft hij deze studie afgesloten met als specialisatie Sociale Psychologie. Vanaf september 1987 tot september 1991 werkte hij als assistent in opleiding bij de vakgroep Gezondheidsvoorlichting van de Rijksuniversiteit Limburg. Gedurende deze periode heeft hij het onderzoek gedaan dat in dit proefschrift beschreven staat. Daarnaast heeft hij over verschillende gerelateerde onderwerpen gepubliceerd. Sinds november 1991 is hij als universitair docent werkzaam bij de vakgroep Communicatiewetenschappen van de Universiteit van Amsterdam. 